\title{
A New Perspective on the Supply and Demand of Weather Services
}

\author{
Cheol Han Bang and Choon Seong Leem* \\ Department of Information \& Industrial Engineering, Yonsei University, Seoul 03722, Korea; chbang@kmiti.or.kr \\ * Correspondence: leem@yonsei.ac.kr
}

Received: 25 September 2020; Accepted: 27 October 2020; Published: 30 October 2020

\begin{abstract}
Despite efforts to estimate the demand for weather services, demand surveys that target only a few consumers with different interests have limitations in providing information about the market gap. This study proposes a method for reversing estimated demand trends by considering new value creation requirements such as national economic power or major industry types. Since no direct surveys of the actual status of services supplied through platforms for the weather service market exist, we investigated the web service status of both public $(n=193)$ and private $(n=144)$ sectors and established a weather service supply classification system. To analyze the global weather service demand environment, members of the World Meteorological Organization were classified according to their characteristics and compared with the supply status. The trend direction was suggested so that suppliers could provide services suitable for demand trends, and the corresponding significance was discussed.
\end{abstract}

Keywords: weather service industry; service supply; demand trend; public and private sector; classification system

\section{Introduction}

Due to increase of abnormal weather phenomena caused by climate change, damage from natural disasters has been expanding and its scale greatly increasing [1,2]. A recent Global Risk Report by the World Economic Forum warns that if our society fails to cope with these weather risks, it will be one of the worst tragedies of this era [3-5]. In fact, climate change poses several risks to businesses, investors, and overall financial stability [6-8]. Since weather risk can directly lead to social and economic losses, an efficient response from the industrial sector is urgently necessary.

According to the National Oceanic and Atmospheric Administration (NOAA), about $80 \%$ of global economic activity is directly or indirectly affected by the weather, and about $10 \%$ of global Gross Domestic Product (GDP) is directly affected by the weather [9]. Moreover, Dutton [10] conducted a qualitative analysis and concluded that in the United States, climate-sensitive areas account for $39.1 \%$ of US GDP. Lazo [11] provided an empirical methodology for estimating industrial activities and found that those directly affected by the climate accounted for 3.4\% of US GDP and that the impact on the household sector was $\$ 31$ billion. Therefore, if weather and climate information is used properly, our society will be able to maintain socioeconomic value beyond mere disaster prevention. Furthermore, if this information is used more actively, high added value may be generated. However, analyses have shown that even though $90 \%$ of businesses are affected by weather and climate events, only $30 \%$ of them respond to such threats [12].

Accordingly, the global society is attempting to strengthen weather services in the public sector $[13,14]$ and is discovering various customized weather services through linkages with the private sector [15-17]. Thus, the market for weather services is becoming increasingly active [18-20], and various types of weather services and weather service companies are being established [21,22]. 
As such, with the availability of weather and climate information, the risks for corporations can be minimized and the scale of profit generation can be accelerated [23]. Indeed, in the global market, weather and climate information are being used as essential business decision-making tools in the industry with the application of weather risk management concepts. Countries and companies are generating profits or reducing losses by developing various solutions that analyze both weather and industrial big data [24-26]. Moreover, the fields of application are comprehensive, the forms are highly diverse, and the weather service sector is expected to continue to grow.

However, weather services have complex characteristics in that the application method is very sensitive and depends on the conditions of use [27] and analyzing the market gap between supply and demand is difficult. Although research regarding potential markets through surveys has recently been attempted to identify the issues, this has limitations [28]. Indeed, market gaps between users and providers of weather services exist, as the services provided often do not match the needs of the users [29-32]. There are distinct differences in values for weather service users. They perceive climate change as a business threat to be concerned about, whereas suppliers view it as a potential business opportunity. While users need weather services to address threats in their areas and industries of interest, suppliers set up strategies to provide specific weather services that they can perform competently. Demand surveys limit clear understanding of the position of all consumers; thus, gaps in such research are inevitable. Addressing this from a new perspective that considers the characteristics of users, different from a question-and-answer demand survey, would be meaningful. In this regard, Georgeson et al. [26] proved that the demand for weather services is closely correlated with national wealth and industrial patterns. Based on the World Bank income group data, spending on weather service is much higher in countries with high national wealth. Therefore, we propose a method for estimating demand trends with a reverse approach by considering other value creation requirements such as national economic power or major industry type.

In this study, we investigate the weather services currently provided in the market and create a classification system. Moreover, after categorizing the countries that provide weather services according to social and environmental characteristics, we analyze the demand for weather services and suggest strategies to enable suppliers to provide services that are suitable to the expected future demand.

\section{Concepts and Definitions}

Weather services concern past, present, and future weather and climate information that is useful for decision-making and, thus, help a variety of industries and economic sectors [33]. In some studies, climate services are referred to separately from weather services [27,34,35]; however, in principle, climate services are considered part of weather services, as is applied in this study [36].

To understand the distribution system of these weather services, organizing the concepts through a service triad is necessary. Service triads involve a tripartite relationship between a provider, a client, and a customer (i.e., end user firm or individual consumer) [37-39]. In service triads, while a service contract is established between a client and a customer, and an agency contract between a client and a provider, there is no contract between the provider and the customer [40]. Figure 1 illustrates the application of this relationship to the weather service sector.

Providers, such as governments and international organizations, invest significantly in the infrastructure and research necessary to provide weather services and in return, obtain data and services from a range of noncommercial bodies with in-house value-adding expertise. Many of these services are freely shared with other public and private sector organizations and provide direct benefits to customers for free [20]. The client part can be regarded as the role of private weather companies. It is not financially viable for a private sector company to produce and collect such massive amounts of weather information, as the return on investment would be insufficient. Thus, these functions have traditionally been executed by government agencies on a large scale. Instead, through customer contracts, private weather companies can provide customized weather services, which the government cannot. 


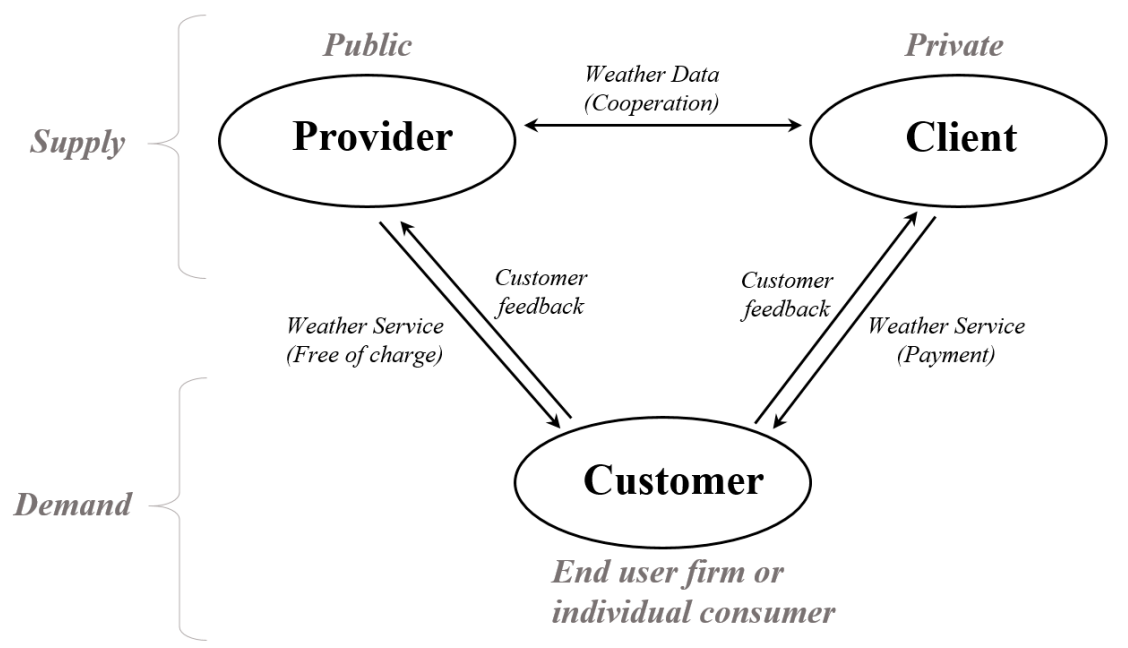

Figure 1. Weather service triad.

This study approaches supply and demand from a new perspective, in that we exclude the cooperative relationship between the provider and the client. Only from the customer's perspective can a classification system be created by examining the weather services available from providers and clients, and a supply strategy is presented by diagnosing the market gap between supply and demand, considering social and environmental factors by country.

\section{Materials and Methods}

\subsection{Fact-Finding Survey}

In the past, the private sector has been overlooked because the public sector has been driving the development and use of weather services. Nevertheless, the private sector serves as a mediator between the provider and the customer, and with its gradually strengthening capabilities, has become indispensable for market growth. Therefore, investigating the supply status of weather services separately in consideration of public and private sector characteristics is necessary.

This study does not classify weather services that can, theoretically be implemented with current technology; rather, it investigates the status of the actual services being provided. Therefore, relevant data were collected based on actual services displayed on the web that are accessible to consumers. Public sector services provide weather information that is universally necessary to protect the lives and property of all citizens of every country from dangerous weather and natural disasters such as floods. Countries with sufficient technology and capital directly produce and provide weather and climate information. Otherwise, indirect services are provided through the websites of neighboring countries or public trust organizations. Since providing weather and forecast information involves astronomical costs, overall production and provision of weather information for a country, in general, are promoted as a public service through cooperation between the government and international organizations. Therefore, when investigating public sector weather services, for accuracy, it is reasonable to examine the service status of the World Meteorological Organization (WMO) member countries that are officially in a global partnership for the service. As of 2020, 193 countries were registered as members of the WMO [41], and all representative websites were surveyed (Table A1).

The private sector focuses on service areas that the public sector does not provide to consumers directly. Thus, weather companies in the private sector upgrade the basic weather information shared by the public sector to provide detailed and customized weather services directly to consumers. Therefore, the reliability of the weather service provided by private meteorological companies depends upon the reliability of the original data provided by the public sector. Although many global weather service companies exist, some sampling criteria have been prepared to ensure service reliability and representativeness. The World Information System (WIS) [42] authorizes Global Information System 
Centres (GISC), which are countries that have the capacity to collect and manage meteorological data through the WIS. There are 15 such countries in total, namely, Australia, Brazil, China, France, Germany, India, Iran, Japan, South Korea, Morocco, Russia, Saudi Arabia, South Africa, Britain, and the United States [43]. Three of them (the United States, Europe, and Japan) have their own weather forecast models, and they reanalyze data production technologies that enable independent weather services [44-46]. Weather companies officially affiliated with these three countries were selected for the survey. Thus, among the 351 weather companies registered with the National Weather Service [47], 106 were targeted for providing weather services (NWS), 22 were registered with the Japan Meteorological Agency (JMA), and 16 were registered with the Association at Private Meteorological Services (PRIMET). Thus, a total of 144 private weather service companies were selected, and all their websites were surveyed (Table A2).

\subsection{Literature Review}

A social environment survey was conducted on a range of WMO member countries to consider the demand groups that reside in countries that are officially aware of the concept of weather services, and the industrial and economic sectors were analyzed and classified. Because there are many major industries in the classification of industries by country, up to three types were prioritized for selection. The national industrial status has been promoted through more than 200 literature surveys, including each national government website and management report. According to the International Classification of Standards (ISIC), industry groups can be divided into 21 types [48]. Based on this, industries that use weather services and have similar characteristics were integrated into 13 industries (Table 1). The classification of economic status by country was determined by examining the WB Official Development Assistance (ODA) Business Policy Report [49] and the Development Assistance Committee (DAC) List [50]. For economic classification, countries were divided into four categories, which was in accordance with the Gross National Income (GNI) per capita in the previous year (Table 2). Thus, the surveyed countries were divided into 52 areas based on both industrial (13 types) and economic sector (four types).

Table 1. Classification of industrial groups for weather services.

\begin{tabular}{|c|c|}
\hline Classification & Contents \\
\hline Agriculture, forestry and fisheries & Agriculture, forestry, and fishing \\
\hline Manufacturing & Manufacturing, mining, and quarrying \\
\hline Energy industry & Electricity, gas, steam, and air conditioning supply \\
\hline Facility management & $\begin{array}{l}\text { Water supply management; sewerage, waste management and } \\
\text { remediation activities }\end{array}$ \\
\hline Construction & Construction \\
\hline Wholesale and retail & Wholesale and retail trade; repair of motor vehicles and motorcycles \\
\hline Transportation and storage & Transportation and storage \\
\hline Hotels and restaurants & Accommodation and food service activities \\
\hline Information and communication & Information and communication \\
\hline Financial and insurance & Financial and insurance activities; real estate activities \\
\hline Scientific and technology & Professional, scientific, and technical activities \\
\hline Health and society & Human health and social work activities; education \\
\hline Recreation and service activities & Entertainment and recreation; art, other service activities \\
\hline
\end{tabular}

Table 2. Classification of economic groups for weather services.

\begin{tabular}{cc}
\hline Contents & Description (\$) \\
\hline High income & GNI $>12,375$ \\
Upper middle income & $3996 \leq \mathrm{GNI} \leq 12,375$ \\
Lower middle income & $1026 \leq \mathrm{GNI} \leq 3995$ \\
Low income & $\mathrm{GNI} \leq 1025$ \\
\hline
\end{tabular}




\section{Results}

\subsection{Public Service Status}

The actual types of weather services offered through government websites were largely classified as weather condition, precipitation, precipitation form, rainfall probability, snowfall, temperature, wind, humidity, wave height, lightning, cyclone and storm, earthquake and volcano, and dust (Table 3). In addition, cross-classification was possible by categories of warning, nowcasting, very short, short, medium, extended, long, and climate, according to the definitions of meteorological forecasting ranges [36,51] (Table 4). The total number of public weather service cases was 1877.

Table 3. Definitions of the actual types of public weather services.

\begin{tabular}{|c|c|}
\hline Division & Service Contents \\
\hline Weather Conditions & $\begin{array}{c}\text { General information on weather conditions including weather icons and } \\
\text { weather commentary }\end{array}$ \\
\hline Precipitation & The presence and quantity of precipitation \\
\hline Precipitation Form & Types of precipitation, such as rain, freezing rain, snow, sleet, and hail \\
\hline Rainfall Probability & Probability information for the possibility of precipitation \\
\hline Snowfall & The amount or depth of snow falling over a period of time \\
\hline Temperature & $\begin{array}{l}\text { Quantitatively indicates the cold and hot temperature of the air, expressed in degrees } \\
\text { Celsius or Fahrenheit temperature, and includes cold wave or heat wave information. }\end{array}$ \\
\hline Wind & Indicates wind direction and wind speed, including information on strong winds \\
\hline Humidity & $\begin{array}{l}\text { The degree to which water vapor is contained in the air, expressed in absolute } \\
\text { humidity and relative humidity; also includes information on dryness. }\end{array}$ \\
\hline Wave Height & $\begin{array}{l}\text { Indicates information about the height between the valley and the floor of the waves, } \\
\text { mainly in the ocean or large lake, and includes tsunami information. }\end{array}$ \\
\hline Lightning & $\begin{array}{l}\text { Information about the discharge between clouds and clouds, or between clouds and } \\
\text { the earth }\end{array}$ \\
\hline Cyclone and Storm & Information on very serious tropical cyclones \\
\hline Earthquake and Volcano & Surveillance Information on earthquakes and volcanoes \\
\hline Dust & Information indicating the degree of suspended solids in the atmosphere \\
\hline
\end{tabular}

The ratio of general weather services for weather conditions, including weather icons and weather descriptions, was the highest at $25.4 \%$ (476 cases), followed by $17.3 \%$ (324 cases) and $11.9 \%$ ( 224 cases) for temperature and wind information, respectively. In addition, although precipitation information was at $10.2 \%$, the ratio of precipitation-related information in the precipitation form $(7.7 \%)$, rainfall probability $(4.0 \%)$, and snowfall (3.8\%) categories was significantly higher at $25.7 \%$. Considering forecast time range, the ratio of short-range weather forecasting service was the highest at $25.6 \%$ (481 cases), followed by warning service at $23.2 \%$ (435 cases). These statistical results allow us to see which services were prioritized by the government in the provision of public weather services (Figure 2).

According to the data, as of 2019, there were 61 high-income, 56 upper-middle-income, 46 lower-middle-income, and 31 low-income countries worldwide. The number of service cases in high-income countries was 1072, in upper-middle-income, 470; in lower-middle-income, 274; and in low-income countries, 61 (Figure 3a). The average number of national services per economic group has been increasing in high-income countries and was at 17.8 in 2016, about 9.3 times higher than that in low-income countries (i.e., 1.9; Figure 3b). In addition, as income increased to higher national units, the proportion of nowcasting and very short categories of forecasting services increased by about $68 \%$ (Figure 4a). This is a result of national investment in areas that require capital and technology for driving a country's own numerical weather forecasting models. By contrast, the diversity of weather services in low-income countries decreased, while the proportion of simple services at the level of 
weather delivery increased. Weather condition services in low-income countries accounted for $57.4 \%$ of all offered services (Figure $4 b$ ).

Table 4. Definitions of meteorological forecasting ranges.

\begin{tabular}{cr}
\hline Ranges & Contents \\
\hline Warning & Real-time weather information, such as warning and alerts \\
\hline Nowcasting & A description of current weather parameters and 0 to 2 h of forecasted weather parameters \\
\hline Very short & Up to 12 hours' description of weather parameters \\
\hline Short & Beyond 12 hours' and up to 72 hours' description of weather parameters \\
\hline Medium & Beyond 72 hours' and up to 240 hours' description of weather parameters \\
\hline Extended & $\begin{array}{r}\text { Beyond 10 days' and up to 30 days' description of weather parameters, usually averaged } \\
\text { and expressed as a departure from climate values for that period }\end{array}$ \\
\hline Long & From 30 days up to two years (include seasonal outlook) \\
\hline Climate & Beyond two years \\
\hline
\end{tabular}

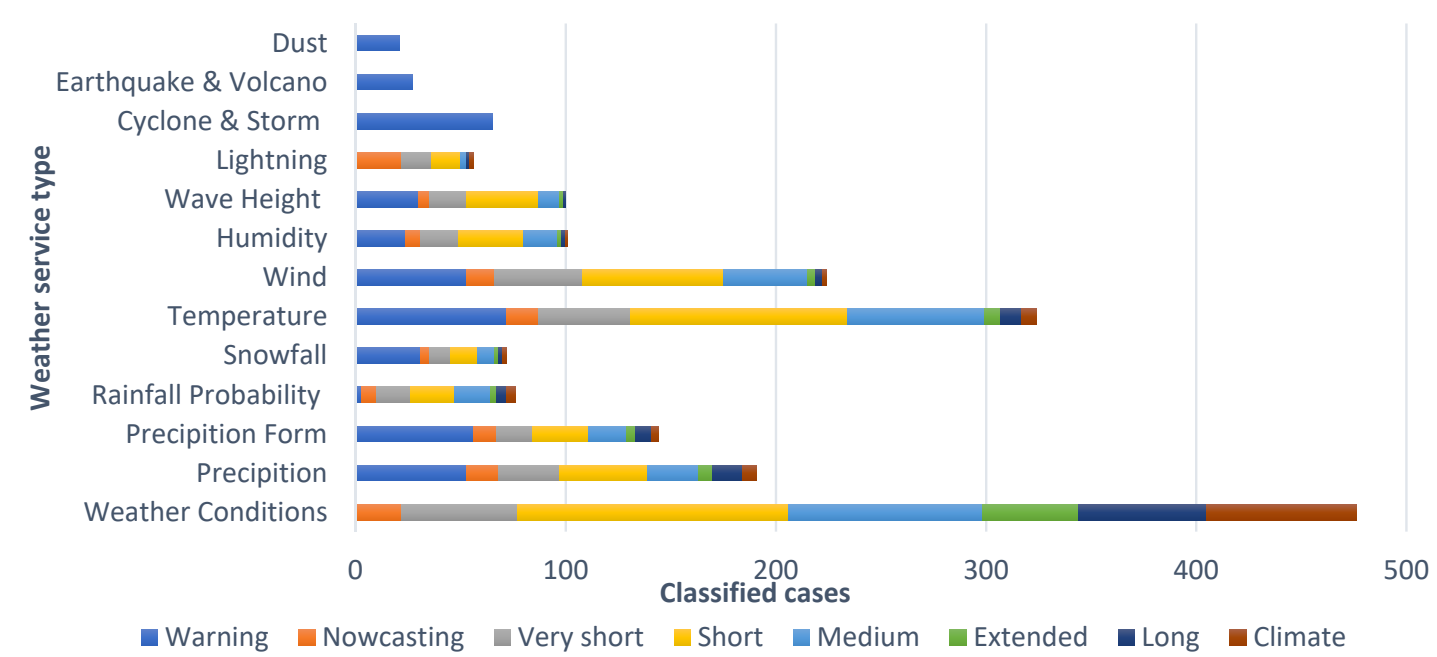

(a)

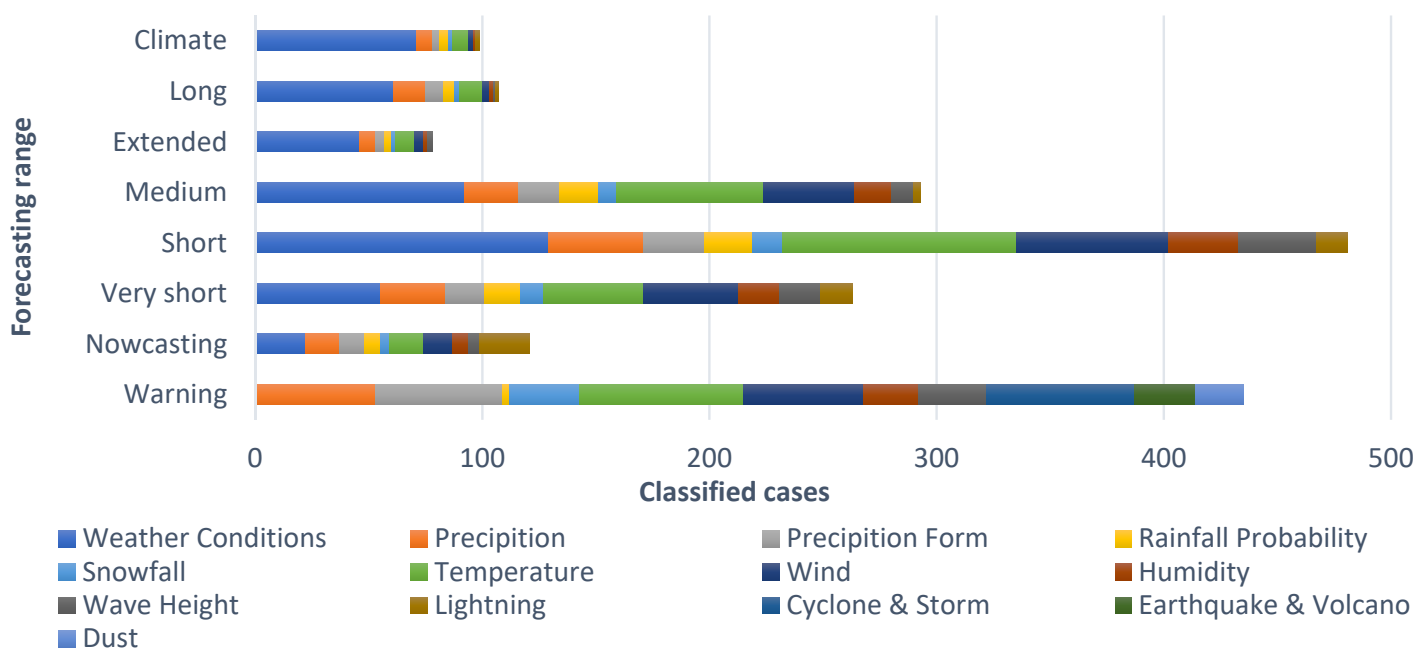

(b)

Figure 2. Analysis of public weather service status by (a) weather service type and (b) forecasting ranges. 


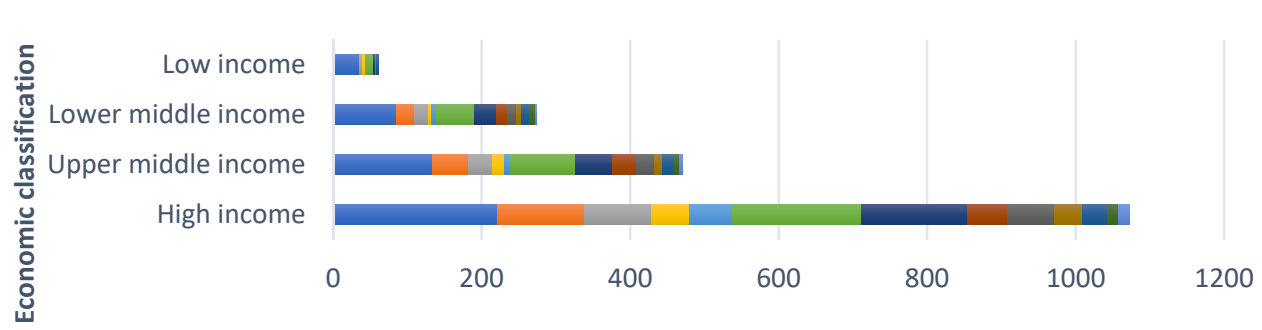

\begin{tabular}{|c|c|c|c|}
\hline $\begin{array}{l}\text { Weather Conditions } \\
\text { Snowfall } \\
\text { Wave Height }\end{array}$ & $\begin{array}{l}\text { Precipition } \\
\text { Temperature } \\
\text { Lightning }\end{array}$ & $\begin{array}{l}\text { Precipition Form } \\
\text { Wind } \\
\text { Cyclone \& Storm }\end{array}$ & $\begin{array}{l}\text { Rainfall Probability } \\
\text { Humidity } \\
\text { Earthquake \& Volcano }\end{array}$ \\
\hline
\end{tabular}

(a)

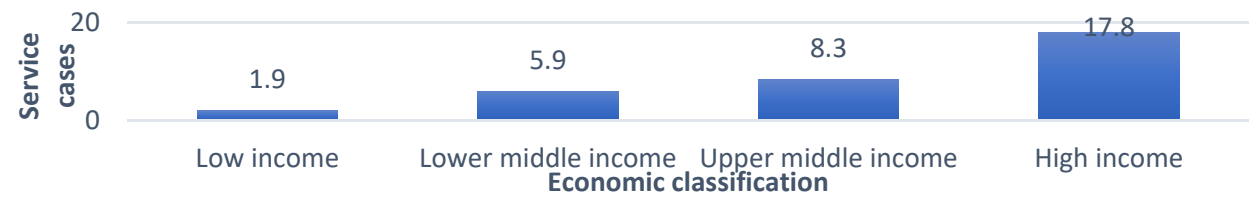

(b)

Figure 3. Public weather service status by national economic classification: (a) by total number of service cases and (b) by average number of service cases per country.

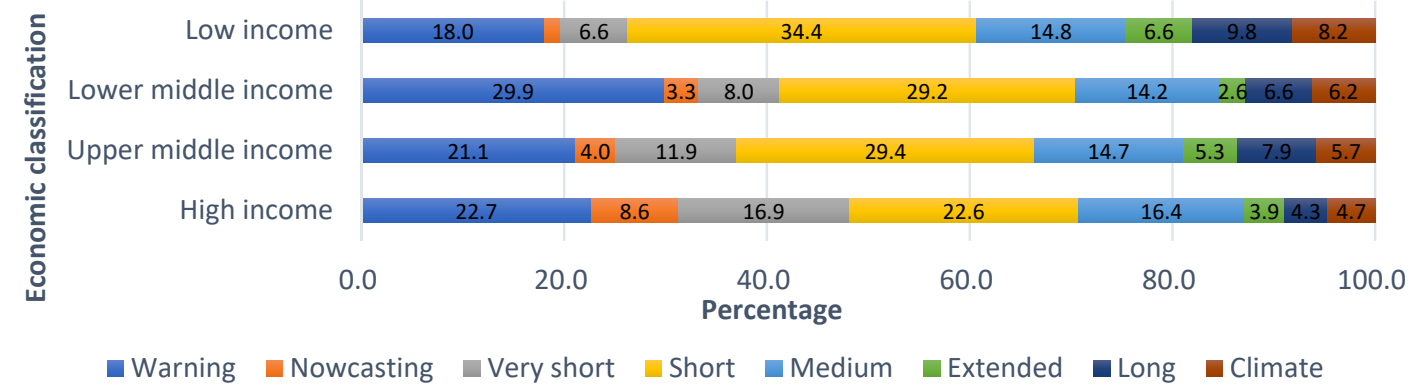

(a)

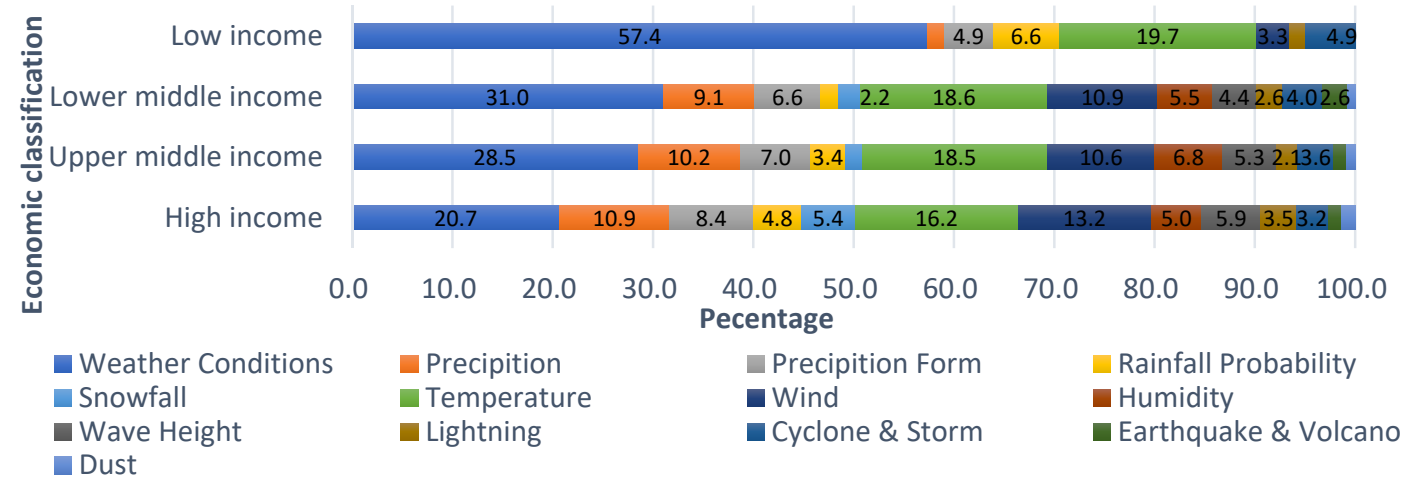

(b)

Figure 4. Distribution chart of public weather services by national economic classification by (a) meteorological forecasting ranges and (b) type of weather services.

\subsection{Private Service Status}

There were 13 categories in the classification of services by related industries to facilitate social environment classification and correlation (as analyzed later in Chapter 3), namely, agriculture, 
forestry, and fisheries; manufacturing; energy; facility management; construction; wholesale and retail; transportation and storage; hotels and restaurants; information and communication; financial and insurance; science and technology; health and society; and recreation and service activities. Following certain classification criteria, the total number of private weather services supplied was 2400. The analysis of the status of private weather services provided by related industries showed that health and society services, which provided raw data of 400 cases $(16.7 \%)$, had the highest volume of services. This was followed by transportation and storage (11.9\%), financial and insurance $(10.0 \%)$, energy $(9.7 \%)$, recreation and service activities $(8.7 \%)$, science and technology $(7.5 \%)$, information and communication $(7.3 \%)$, construction $(6.2 \%)$, facility management $(4.5 \%)$, wholesale and retail $(3.8 \%)$, manufacturing $(3.4 \%)$, and hotels and restaurants (1.8\%; Figure 5a). In most industrial categories, the concentration of the health and society service sector was strong (Figure $5 b$ ).

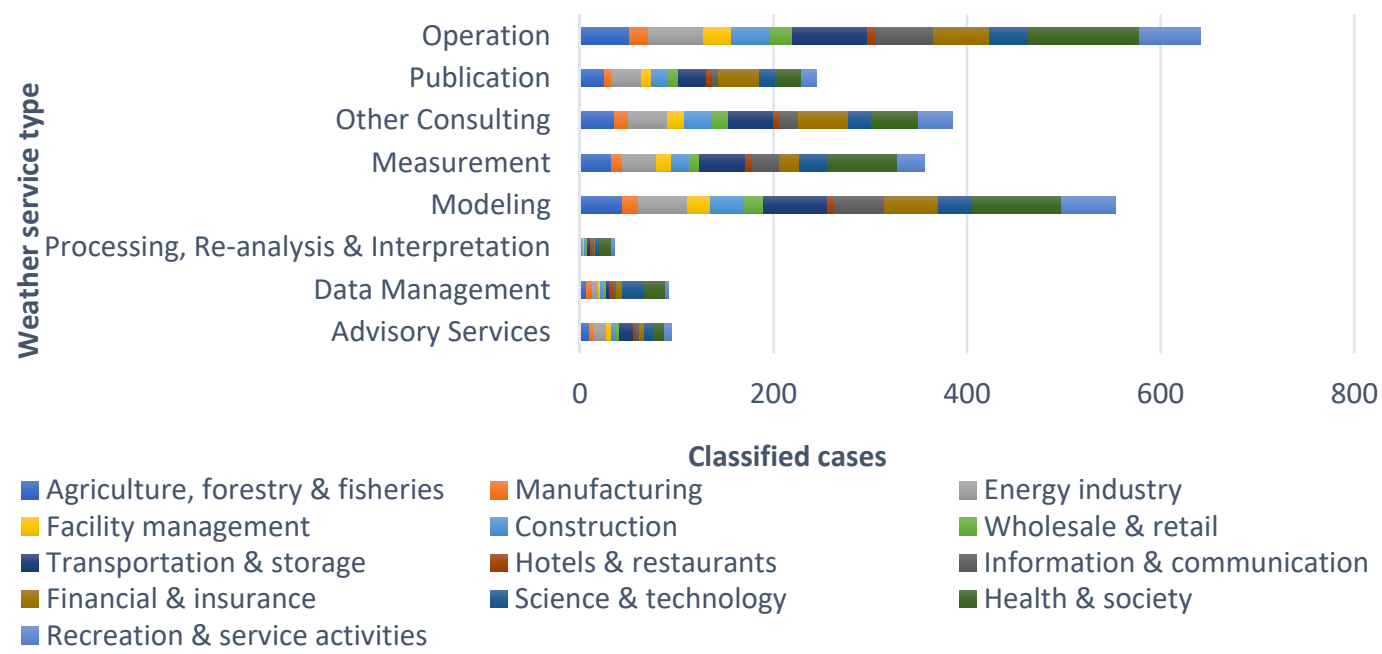

(a)

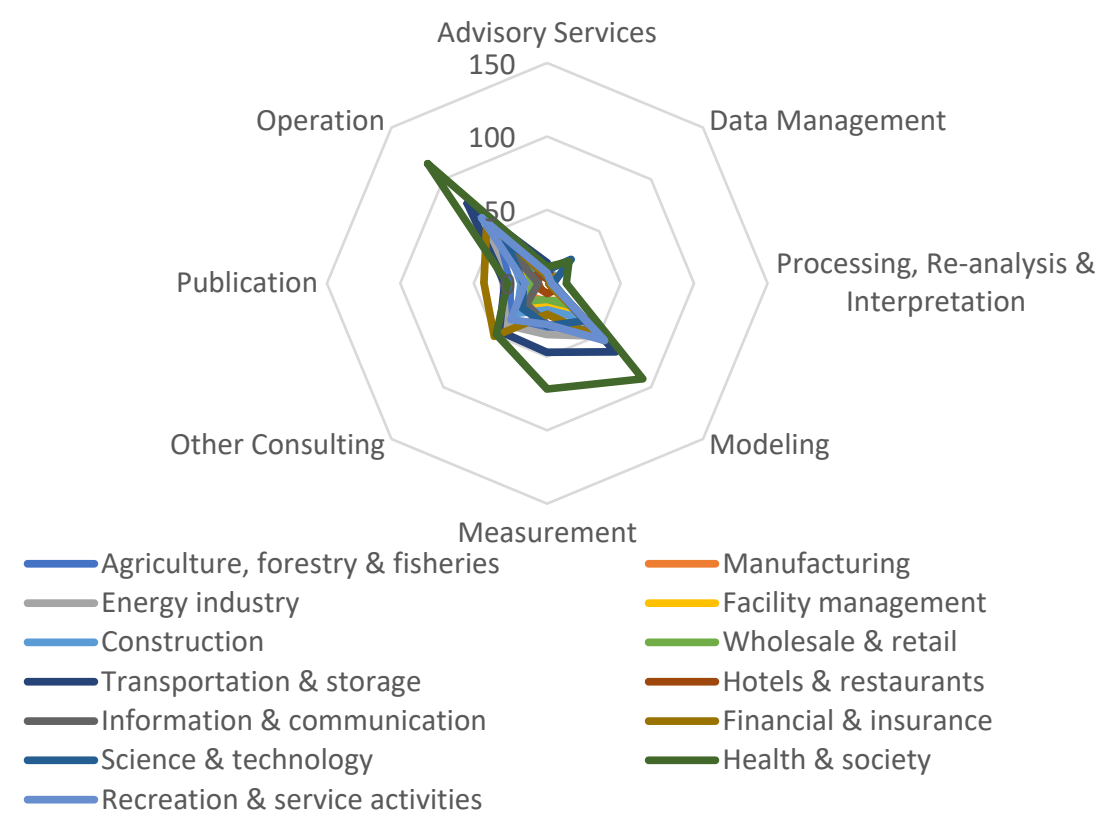

(b)

Figure 5. Analysis of (a) the private weather service status and (b) the concentration of that service by weather service type. 
In addition, the types of private weather services actually offered at the website of private weather companies were largely classified as advisory, data management, measurement, modeling, operation, other consulting, and processing reanalysis and interoperability publication (Table 5). This was based on the classification of services defined in the study of the Market Research for a Climate Services Observatory (MARCO) [20]. The analysis of the status of supply cases of private weather services by weather service type showed that operation services, which provided raw data of 641 cases $(26.7 \%)$ had the highest volume of services, followed by modeling service (23.0\%), other consulting $(16 \%)$, measurement $(14.8 \%)$, publication $(10.2 \%)$, advisory $(3.9 \%)$, data management $(3.8 \%)$, and processing reanalysis and interpretation (1.5\%; Figure 6a). In most industrial categories, the concentration of the operation service sector was strong (Figure $6 \mathrm{~b}$ ). According to the MARCO report, in terms of transactions, advisory ranked the highest at 890,400 (25\%), followed by other consulting $(21 \%)$, processing reanalysis and interpretation $(12 \%)$, modeling $(12 \%)$, measurement $(10 \%)$, publication $(8 \%)$, operation (7\%), and data management (6\%; Figure 7$)$.

Table 5. Definitions of the actual types of private weather services.

\begin{tabular}{|c|c|}
\hline Service Type & Contents \\
\hline Advisory & $\begin{array}{c}\text { Advisory services, risk assessment, and decision support tools provided to } \\
\text { public and private sector organizations relevant to global weather, } \\
\text { climate and climate change, i.e., risk assessment for the long-term location of } \\
\text { nuclear power stations. }\end{array}$ \\
\hline Data Management & $\begin{array}{l}\text { Provision of calibrated data sets, data archiving, data certification, and data } \\
\text { sales for global weather, climate and climate change applications, } \\
\text { i.e., the provision of validated data sets to consultancies for further analysis. }\end{array}$ \\
\hline Measurement & $\begin{array}{l}\text { Instruments and technologies for measurement and calibration for global } \\
\text { weather, climate and climate change applications, i.e., the provision of } \\
\text { assistance and advice in the assembly of sensing arrays for ground-based } \\
\text { weather stations. }\end{array}$ \\
\hline Modelling & $\begin{array}{l}\text { Modeling of data, both certified and non-certified, for global weather, } \\
\text { climate and climate change, i.e., the modelling of collated data from the arctic } \\
\text { survey to predict the most likely rate of degradation of the polar ice cap. }\end{array}$ \\
\hline Operation & $\begin{array}{l}\text { Collection and provision of raw data for global weather, climate and climate } \\
\text { change applications i.e., the provision of raw date to media weather centers. }\end{array}$ \\
\hline Other Consulting & $\begin{array}{l}\text { Consulting services for global weather, climate and climate change not } \\
\text { elsewhere covered, i.e., the provision of advice on corporate statements to } \\
\text { shareholders on corporate policy towards climate change. "Other Consulting" } \\
\text { often includes more general consulting services about corporate responses to } \\
\text { the challenges arising from specific weather and climate data (whether } \\
\text { purchased separately or processed internally) and also more specialist } \\
\text { services (incorporation of new data sets). }\end{array}$ \\
\hline $\begin{array}{l}\text { Processing, } \\
\text { Reanalysis and Interpretation }\end{array}$ & $\begin{array}{l}\text { Provision of data analysis and retrieval services including data mining tools, } \\
\text { for global weather, climate and climate change, i.e., the provision of essential } \\
\text { climate variable models to academia. }\end{array}$ \\
\hline Publication & $\begin{array}{l}\text { General publication of analysis findings for global weather, climate and } \\
\text { climate change, i.e., the assembly of publications on climate forecasts based } \\
\text { on data and analysis for both private and public sector organizations. }\end{array}$ \\
\hline
\end{tabular}




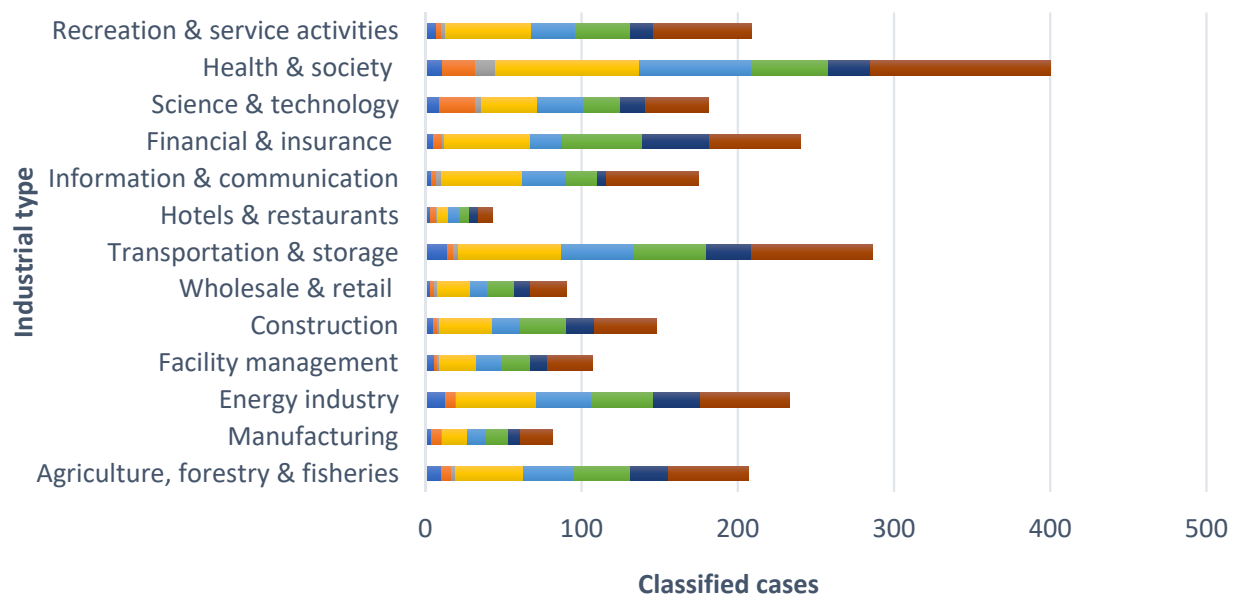

Advisory Services

Processing, Re-analysis \& Interpretation

Measurement

- Publication
Data Management
- Modeling
- Other Consulting
- Operation

(a)

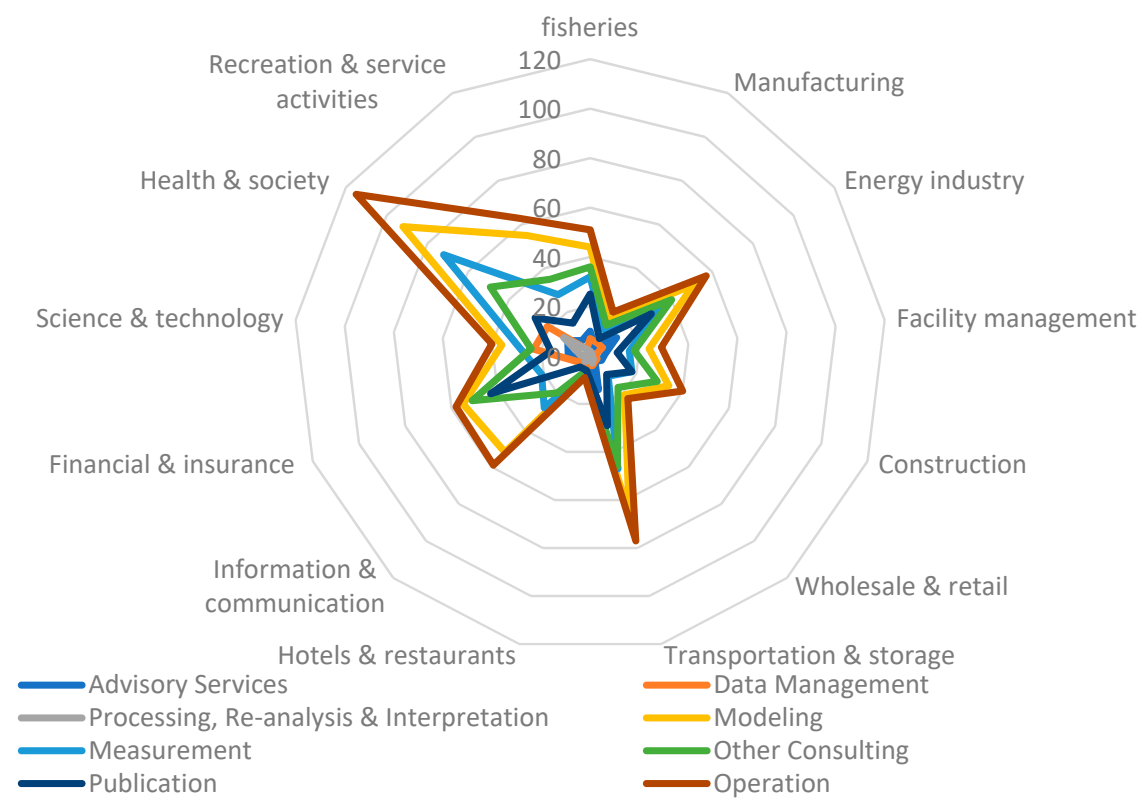

(b)

Figure 6. Analysis of (a) private weather service status and (b) the concentration of that service by related industries.

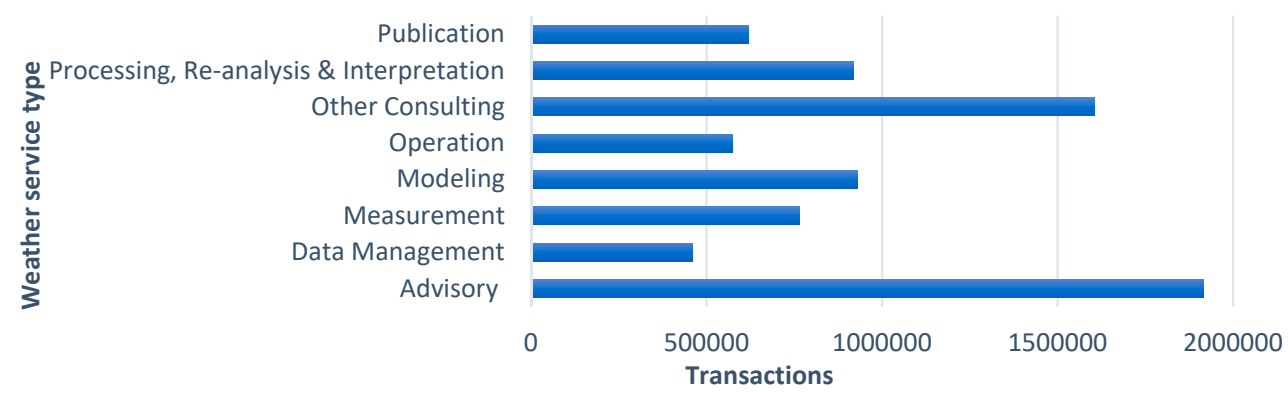

Figure 7. Volume of weather service transactions by service type. 
Both the supply and transaction volumes of these quantitatively investigated weather services show differences in patterns among them. For example, the operation service had the highest supply volume but the lowest transaction volume. High supply means that the unit cost tends to be low because of many competitors. A high supply and low unit cost but low transaction volume mainly indicates that demand has risen from services with low willingness to pay (WTP). By contrast, low supply means that there is high tendency toward a high unit cost due to fewer competitors. Low supply with high unit cost but high transaction volume results from rising demand for services with high WTP. By contrast, low supply means that high unit cost is quite likely due to fewer competitors. Low supply with high unit cost but high transaction volume mainly indicates that demand has risen for services with high WTP. The trend was analyzed by calculating the ratio of supply to transaction volume for each weather service type and converting the maximum value to 1 (Figure $8 \mathrm{a}$ ). The average of expenditures for meteorological services per capita (in dollars) for countries classified by development status based on the World Bank Income Group were 0.89 (for low-income countries), 2.35 (low-middle), 5.65 (high-middle), and 19.83 (high-income). Figure $8 \mathrm{~b}$ shows the trend by converting the maximum value to 1 so that a comparison can be made with Figure 8a. Based on this figure, operation services is likely to be in demand for the low-income countries. The WTP trend value for the lower-middle-income countries is 0.12 , which is a likely range of demand for operation to publication services. Similarly, for upper-middle-income countries, data management service is likely to be in demand, and for high-income countries, all services are within the range of demand (Figure 8c). Based on these results, the taxonomy table is presented for diagnosing the types of weather services likely to be in demand in accordance with the national social environment (i.e., national income and industrial characteristics; Table 6). The taxonomy lists the industry (I) classifications on the vertical axis and the economy (E) classifications on the horizontal axis. An IE code was assigned to each cell and configured to allow estimation of the range of weather service types that are likely to be suitable for each code. This table can serve to diagnose which type of service the supplier should be more interested in, mainly considering the industry characteristics and economic conditions of the supplier's target demand.

Table 6. Taxonomy table for diagnosing the types of weather services that are likely to be in demand according to the national social environment (i.e., national income and industrial characteristics).

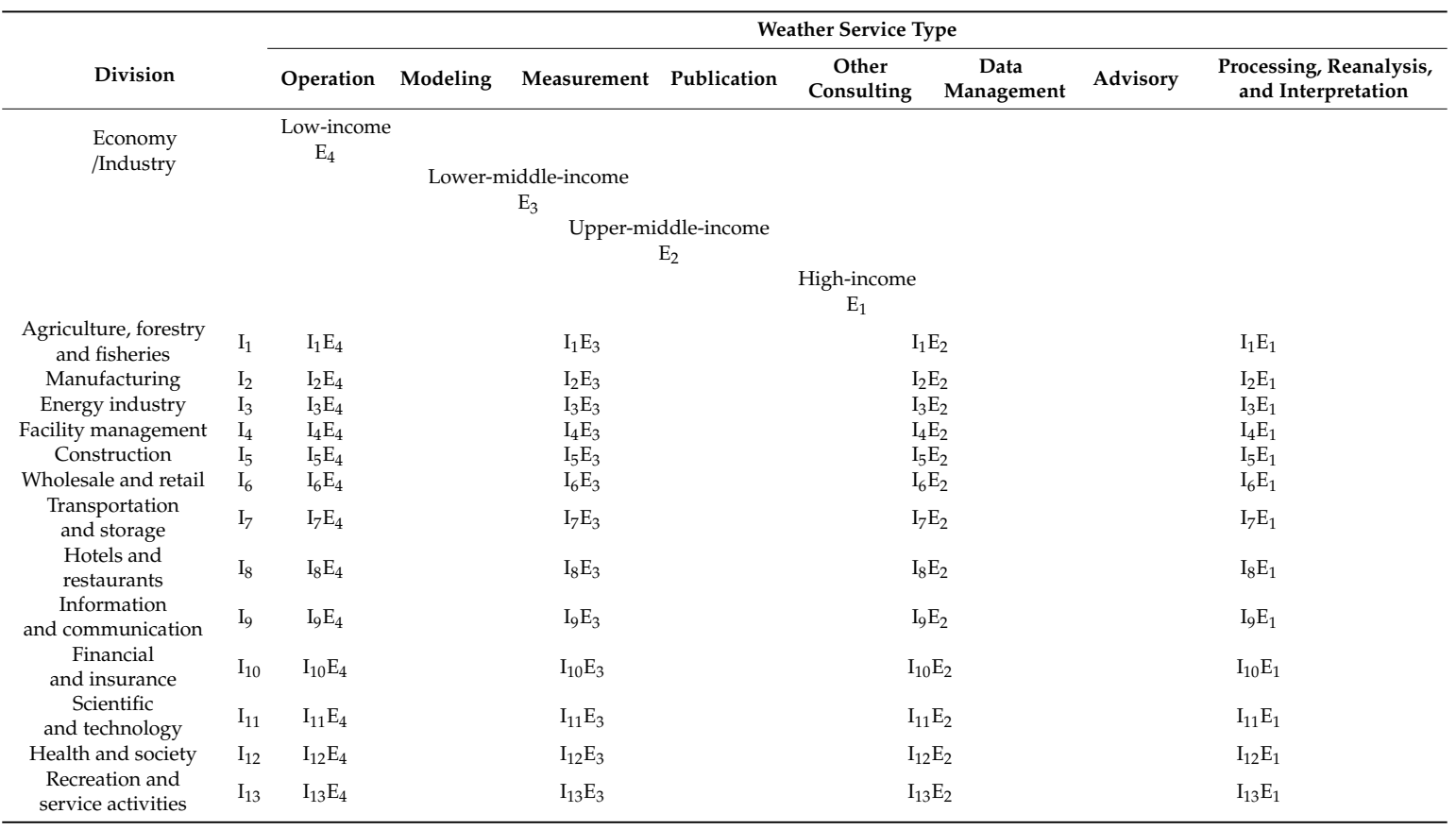




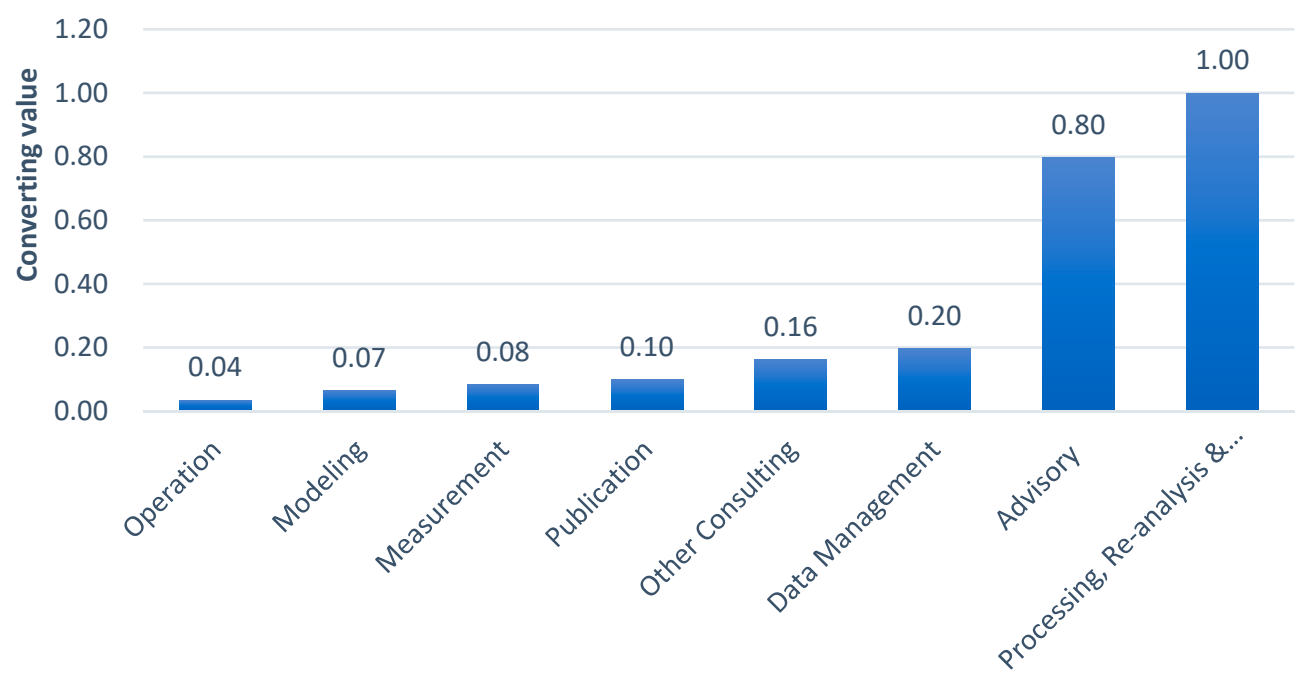

Weather service type

(a)

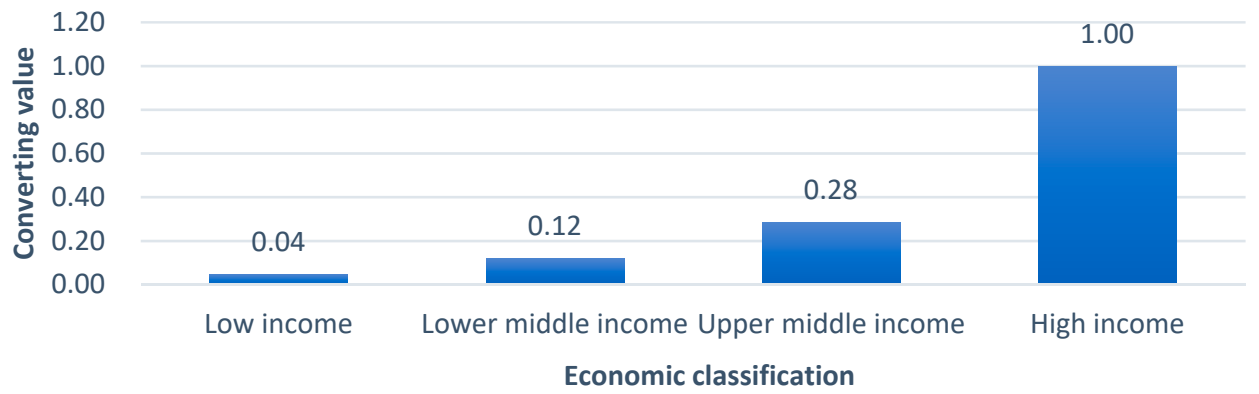

(b)

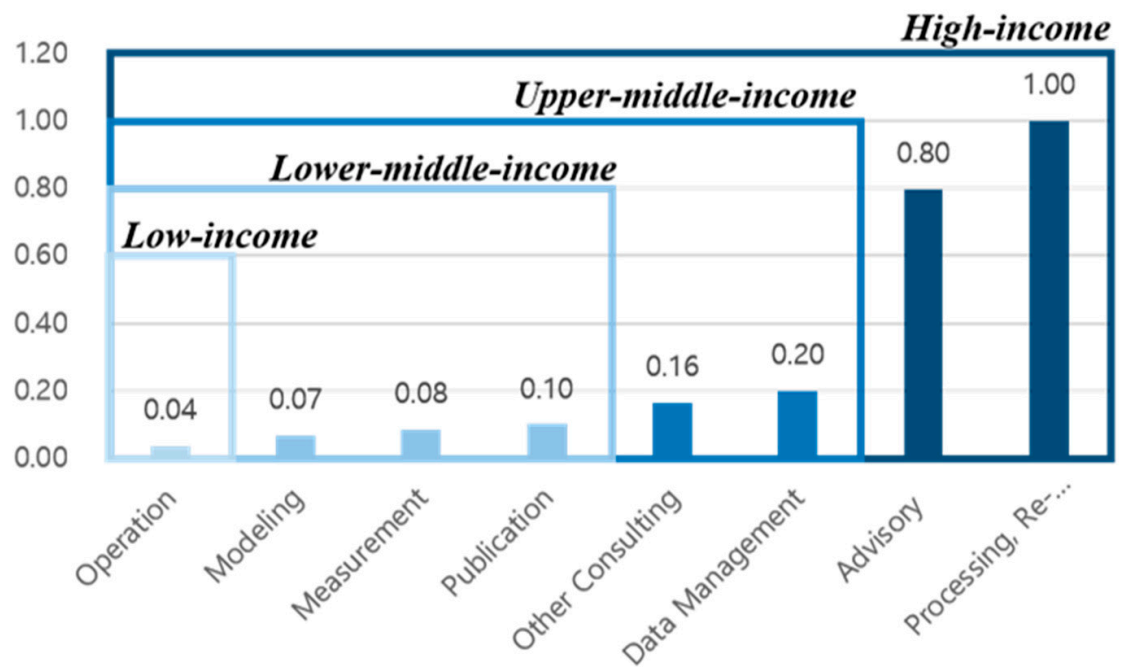

(c)

Figure 8. (a) Ratio trend of the supply volume to the transaction volume by type of weather service, (b) willingness to pay (WTP) trend according to national economic level classification, and (c) estimation of the range of major weather services that are likely to be in demand based on the national economic level. 


\subsection{Social Environment Classification}

In the national social environmental analysis, the number of cases, at 1029, was derived according to the classification criteria. According to the industry analysis, manufacturing ranked highest for the largest number of industries, with 295 cases $(28.7 \%)$, followed by agriculture, forestry, and fisheries (22.1\%), hotels and restaurants $(10.3 \%)$, health and society $(7.7 \%)$, energy $(6.7 \%)$, construction $(5.4 \%)$, transportation and storage (5.3\%), and availability management (1.0\%). According to the analysis by economic level, 303 cases $(29.4 \%)$ were included in the category of upper-middle-income countries, which was the largest group, followed by high-income (28.3\%), lower-middle-income $(24.5 \%)$, and low-income $(17.8 \%)$ countries. For the recreation and service activities and science and technology categories, high-income countries accounted for more than three quarters. Thus, these industries are likely to have sufficient demand in high-income countries. The lower the income level, the greater is the proportion of agriculture, forestry, and fisheries, and health sectors in major projects. This implies that these industries are likely to have sufficient demand in low-income countries. However, the proportion of the hotels and restaurants and recreation and service industries tended to decrease, which is likely because countries with lower income levels have more difficulty in activating weather services.

\section{Discussion}

From the suppliers' perspective, the supply of weather services to the public sector focused on providing simple information on weather factors and weather conditions according to weather forecasting time. Meanwhile, the supply of weather services in the private sector was divided by industry, where various service types were provided. This results from the mutually complementary relationship between the public and private sectors, as previously defined in the weather service triad. We compared the actual supply status directly surveyed and the transaction status investigated in the prior study to confirm that the gap between demand and supply occurs for each type of weather service. We were able to derive new supply strategies based on the characteristics of the demand source and the research result that social environment affects the demand for weather service.

According to the classification by national economic level, the case of the group of high-income countries accounted for $28.3 \%$, whereas the size of weather services accounted for $57.1 \%$, of the total service. From the customer's perspective, the higher the national economic level, the higher are the benefits from public weather services. Therefore, consumers in high-income countries have little incentive to pay for private weather services. However, it is likely that there will be demand for specific weather services such as advisory on processing and reanalysis, and interpretations, which have high WTP, for corporate decision-making in the high-income market. According to the classification by national economic level, the case of low-income countries accounted for $17.8 \%$, whereas the size of weather services accounted for $3.2 \%$, of the total service. Because the weather services that consumers can receive from the public sector are limited, customers who need weather services must obtain their desired services from the private sector. Since low-income countries have low WTP, it is expected that in these countries, private service demand for operational weather services that mainly focus on raw data will increase. Similarly, the data analyzed in this study between public and private sector services point to the future direction of commercialization of weather services. From the analysis of the status of private weather service supply, we found that weather services in the health and society sector are intensively serviced regardless of type. Amid the recent spread of coronavirus disease (COVID-19) pandemic, the health sector is expected to become even more critical [52], such that weather considerations would be essential to determining the rate of COVID-19 outbreaks. Meanwhile, in the analysis of social environment by country, health and society industries are expected to grow in underdeveloped countries. Thus, it is reasonable to consider actively expanding health services that apply weather services as required by underdeveloped countries.

The results of the social environment analysis conducted on WMO-member countries shows that I2E2 has the highest rate, with 83 cases (Figure 9). Thus, weather services such as other consulting, data management, which corresponds to the manufacturing sector of upper-middle-income countries 
are most likely to generate demand. By contrast, since services were found to be relatively low in concentration, efforts to secure a market for these services are likely to create demand. Referencing the classification table in this way can help develop a response plan for weather service businesses, based on IE characteristics by country. This is of great significance because it presents a new perspective on the supply and demand of meteorological services, as it breaks away from the existing method of preparing a supply plan by identifying demand based on a consumer survey.

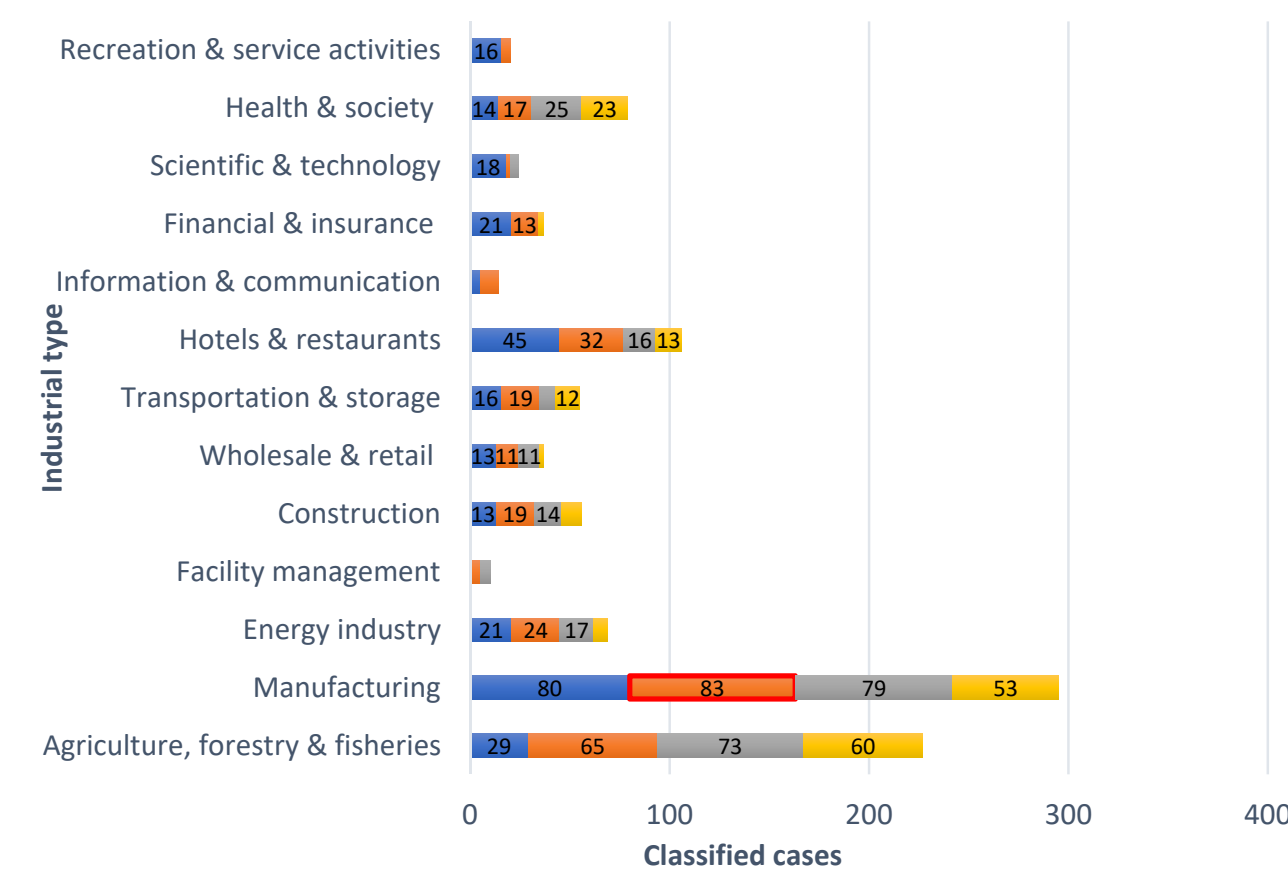

- High income $\square$ Upper middle income $\quad$ Lower middle income

(a)

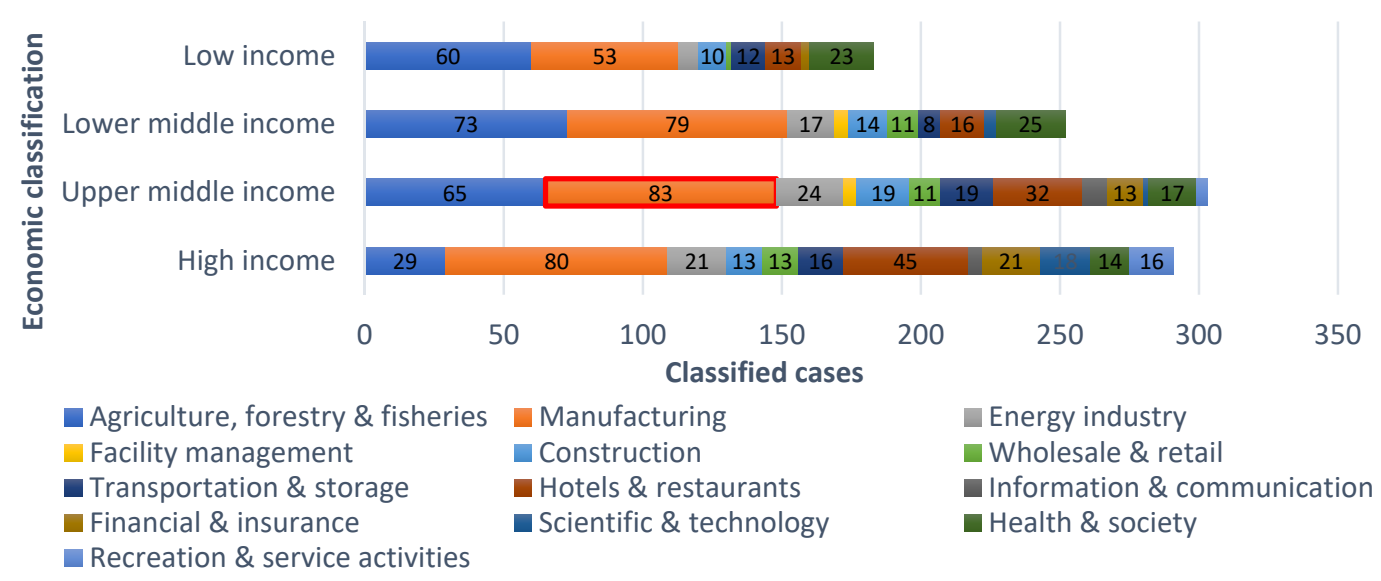

(b)

Figure 9. Analysis of (a) the characteristics of national income groups by major industry classification and (b) major industry classification by national income group.

This study is designed to estimate the real demand by comparing the actual supply status of weather services surveyed by the author with the transaction status surveyed in previous studies, to identify the gap between supply and demand, find trends, and estimate real demand. To derive the actual supply status of weather services, we conduct a thorough survey of web sites that have been 
sampled and adopt a methodology to derive statistical data of meteorological service, by standardizing vast amounts of unstructured information. For this reason, there are limitations in the statistics creation and analysis, and uncertainties arising from this issue need to be partially improved. In addition, the proposed measures also need to be flexibly applied according to the volatility of each country's industrial structure and economic growth over time.

In the future, studies that apply a methodology similar to this one, or organically combine other improved methodologies to interview surveys and/or research cases, will yield better results in resolving the supply and demand gap. In addition, adding climatic conditions not considered in this study to the analysis of social environment would be a good attempt to find an improved method. We are confident that if we continue to secure various perspectives to reduce the gap between supply and demand of meteorological services, we will ultimately be able to expect positive effects in expanding the weather service market.

Author Contributions: C.H.B. contributed to the following: the conception and design of the study, acquisition of data, analysis and interpretation of data, drafting of the article, and approval of the submitted version. C.S.L. provided assistance regarding the methodology. All authors have read and agreed to the published version of the manuscript.

Funding: This research received no external funding.

Conflicts of Interest: The authors declare no conflict of interest.

\section{Appendix A}

Table A1. Weather service supply channel of the public sector.

\begin{tabular}{|c|c|c|}
\hline Nation & Government Meteorological Authority & Website \\
\hline Albania & The Hydrometeorological Institute & no website provided \\
\hline Algeria & Office National de la Météorologie & http://www.meteo.dz/ \\
\hline Andorra & Environment Minister Goberne DeNierto & no website provided \\
\hline Argentina & Servicio Meteorológico Nacional & https://www.smn.gob.ar/ \\
\hline Armenia & Armenian State Hydro and Monitoring Service & http://www.meteo.am/ \\
\hline Australia & Bureau of Meteorology & http://www.bom.gov.au/ \\
\hline Austria & Central Institute for Meteorology and Geodynamics & http://www.zamg.ac.at/ \\
\hline Bahrain & Bahrain Meteorological Service & http://www.bahrainweather.com/ \\
\hline Bangladesh & Bangladesh Meteorological Department & http://www.bmd.gov.bd/ \\
\hline Barbados & Meteorological Services & http://www.barbadosweather.org/ \\
\hline Belarus & Department of Hydrometeorology & http://www.pogoda.by/ \\
\hline Belgium & Institut Royal Météorologique & http://www.meteo.be/ \\
\hline Belize & National Meteorological Service & http://www.hydromet.gov.bz/ \\
\hline Benin & Service Météorologique National & http://www.meteo-benin.net/ \\
\hline Bhutan & Council for Renewable Natural Resources Research & no website provided \\
\hline Bulgaria & National Institute of Meteorology and Hydrology & http://www.meteo.bg/ \\
\hline
\end{tabular}


Table A1. Cont.

\begin{tabular}{|c|c|c|}
\hline Nation & Government Meteorological Authority & Website \\
\hline Burkina Faso & Direction de la Météorologie & http://www.meteo-burkina.net/ \\
\hline Burundi & Institut Géographique du Burundi & no website provided \\
\hline Cambodia & Department of Meteorology & http://www.cambodiameteo.com/ \\
\hline Cameroon & Direction de la Météorologie Nationale & no website provided \\
\hline Central African Rep. & $\begin{array}{l}\text { Direction Générale de l'Aviation Civile } \\
\text { et de la Météorologie }\end{array}$ & no website provided \\
\hline Chad & Direction des Ressources en Eau et de la Météorologie & no website provided \\
\hline Chile & Dirección Meteorológica de Chile & http://www.meteochile.cl/ \\
\hline Comoros & Direction de la Météorologie Nationale & no website provided \\
\hline Congo, Dem. Rep. & $\begin{array}{l}\text { Agence Nationale de Météorologie et de } \\
\text { Télédétection par Satellite }\end{array}$ & http://www.meteo-congo-kinshasa.net/ \\
\hline Congo, Rep. & Direction de la Météorologie Nationale & http://www.meteo-congo-brazza.net/ \\
\hline Cook Islands & Cook Islands Meteorological Service & http://www.cookislands.pacificweather.org/ \\
\hline Costa Rica & Instituto Meteorológico Nacional & http://www.imn.ac.cr/ \\
\hline Côte d'Ivoire & Direction de la Météorologie Nationale & no website provided \\
\hline Croatia & Meteorological and Hydrological Service & http://meteo.hr/ \\
\hline Dominica & Dominica Meteorological Services & http://www.weather.gov.dm/ \\
\hline Dominican Rep. & Oficina Nacional de Meteorolog iá & http://www.indrhi.gob.do/ \\
\hline Ecuador & $\begin{array}{c}\text { Instituto Nacional de Meteorología e } \\
\text { Hidrología (INAMHI) }\end{array}$ & http://www.serviciometeorologico.gob.ec/ \\
\hline Egypt & The Egyptian Meteorological Authority & http://www.nwp.gov.eg/ \\
\hline El Salvador & Servicio Nacional de Estudios Territoriales & http://www.snet.gob.sv/ \\
\hline Eritrea & Civil Aviation Authority & no website provided \\
\hline Estonia & Estonian Meteorological and Hydrological Institute & http://www.emhi.ee/ \\
\hline Ethiopia & National Meteorological Services Agency & http://www.ethiomet.gov.et/ \\
\hline Fiji & Fiji Meteorological Service & http://www.met.gov.fj/ \\
\hline Finland & Finnish Meteorological Institute & http://www.fmi.fi/ \\
\hline France & Météo-France & http://www.meteo.fr/ \\
\hline French Polynesia & Météo-France Polynesie Francaise & http://www.meteo.pf/ \\
\hline Gabon & Direction de la Météorologie Nationale & no website provided \\
\hline Gambia & Department of Water Resources & no website provided \\
\hline Georgia & Department of Hydrometeorology & http://www.hydromet.ge/ \\
\hline
\end{tabular}


Table A1. Cont.

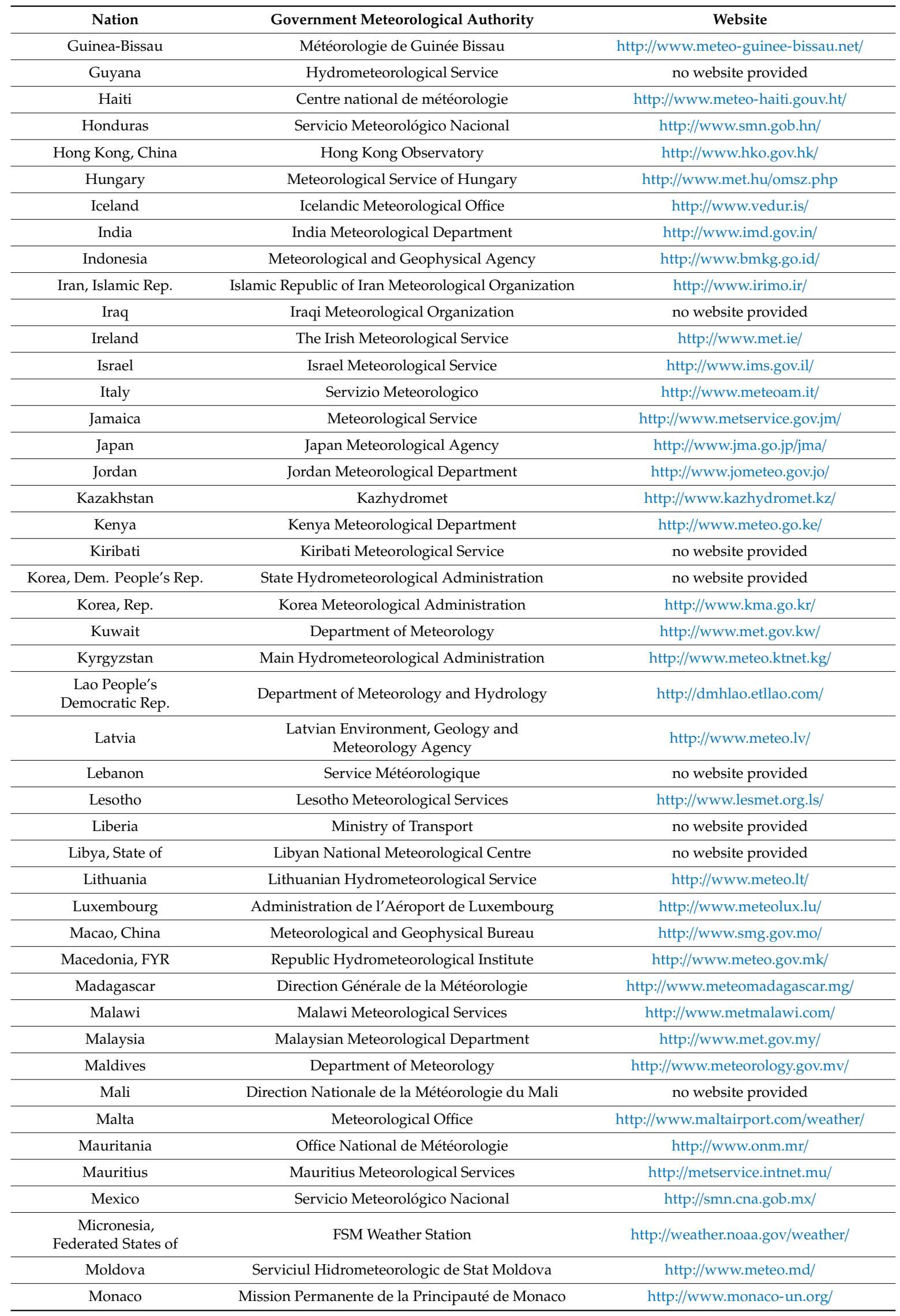


Table A1. Cont.

\begin{tabular}{|c|c|c|}
\hline Nation & Government Meteorological Authority & Website \\
\hline Mongolia & $\begin{array}{l}\text { National Agency for Meteorology, Hydrology and } \\
\text { Environment Monitoring }\end{array}$ & no website provided \\
\hline Montenegro & Hydrometeorological Institute of Montenegro & http://www.meteo.co.me/ \\
\hline Morocco & Direction de la Météorologie Nationale & http://www.marocmeteo.ma/ \\
\hline Mozambique & Instituto Nacional de Meteorologia & http://www.inam.gov.mz/ \\
\hline Myanmar & Department of Meteorology and Hydrology & http://www.dmh.gov.mm/ \\
\hline Namibia & Namibia Meteorological Service & http://www.meteona.com/ \\
\hline Nauru & Department of National Emergency Services & no website provided \\
\hline Nepal & Department of Hydrology and Meteorology & http://www.dhm.gov.np/ \\
\hline Netherlands & Royal Netherlands Meteorological Institute & http://www.knmi.nl/ \\
\hline New Caledonia & Météo-France Nouvelle Calédonie & http://www.meteo.nc/ \\
\hline New Zealand & New Zealand National Meteorological Service & http://www.metservice.co.nz/ \\
\hline Nicaragua & Dirección General de Meteorología & http://www.ineter.gob.ni/ \\
\hline Niger & Direction de la Météorologie Nationale & http://www.meteo-niger.net/ \\
\hline Nigeria & Nigerian Meteorological Agency & http://nimet.gov.ng/ \\
\hline Niue & Niue Meteorological Service & http://informet.net/niuemet \\
\hline Norway & Norwegian Meteorological Institute & http://www.met.no/ \\
\hline Oman & Department of Meteorology & http://www.met.gov.om/ \\
\hline Pakistan & Pakistan Meteorological Department & http://pmd.gov.pk/ \\
\hline Panama & Hidrometeorología & http://www.hidromet.com.pa/ \\
\hline Papua New Guinea & Papua New Guinea Meteorological Service & http://www.pi-gcos.org/ \\
\hline Paraguay & Dirección de Meteorología e Hidrología & http://www.meteorologia.gov.py/ \\
\hline Peru & Servicio Nacional de Meteorología e Hidrología & http://www.senamhi.gob.pe/ \\
\hline Philippines & $\begin{array}{l}\text { Philippine Atmospheric Geophysical and } \\
\text { Astronomical Services Administration }\end{array}$ & http://www.pagasa.dost.gov.ph/ \\
\hline Poland & Institute of Meteorology and Water Management & http://www.imgw.pl/ \\
\hline Portugal & Instituto de Meteorologia & http://www.meteo.pt/ \\
\hline Qatar & Civil Aviation Authority & http://qweather.gov.qa/ \\
\hline Romania & National Meteorological Administration & http://www.inmh.ro/ \\
\hline Russian Federation & $\begin{array}{c}\text { Russian Federal Service for Hydrometeorology and } \\
\text { Environmental Monitoring }\end{array}$ & http://www.meteorf.ru/ \\
\hline Rwanda & Rwanda Meteorological Agency & http://www.meteorwanda.gov.rw/ \\
\hline Saint Lucia & Meteorological Services & http://www.cdera.org/weather/ \\
\hline Samoa & Samoa Meteorology Division & http://www.mnre.gov.ws/ \\
\hline Sao Tome and Principle & Institut National de Météorologie & no website provided \\
\hline Saudi Arabia & Presidency of Meteorology and Environment & http://www.pme.gov.sa/ \\
\hline Senegal & Direction de la Météorologie Nationale & http://www.meteo-senegal.net/ \\
\hline Serbia & Republic Hydrometeorological Service of Serbia & http://www.meteo.rs/ \\
\hline Seychelles & National Meteorological Services & http://www.meteo.gov.sc/ \\
\hline Sierra Leone & Meteorological Department & no website provided \\
\hline Singapore & Meteorological Services Division & http://www.weather.gov.sg/ \\
\hline Slovakia & Slovak Hydrometeorological Institute & http://www.shmu.sk/ \\
\hline Slovenia & Meteorological Office & http://www.rzs-hm.si/ \\
\hline Solomon Islands & Solomon Islands Meteorological Service & http://www.met.gov.sb/ \\
\hline Somalia & Permanent Mission of Somalia & no website provided \\
\hline South Africa & South African Weather Service & http://www.weathersa.co.za/ \\
\hline South Sudan & South Sudan Weather Service & no website provided \\
\hline Spain & Agencia Estatal de Meteorología & http://www.aemet.es/ \\
\hline Sri Lanka & Department of Meteorology & http://www.meteo.slt.lk/ \\
\hline
\end{tabular}


Table A1. Cont.

\begin{tabular}{|c|c|c|}
\hline Nation & Government Meteorological Authority & Website \\
\hline Sudan & Sudan Meteorological Authority & http://www.ersad.gov.sd/ \\
\hline Suriname & Meteorological Service & http://www.meteosur.sr/ \\
\hline Sweden & Swedish Meteorological and Hydrological Institute & http://www.smhi.se/ \\
\hline Switzerland & MeteoSwiss & http://www.meteoswiss.ch/ \\
\hline Tajikistan & $\begin{array}{l}\text { Main Administration of Hydrometeorology and } \\
\text { Monitoring of the Environment }\end{array}$ & http://www.meteo.tj/ \\
\hline Tanzania & Tanzania Meteorological Agency & http://www.meteo.go.tz/ \\
\hline Thailand & Thai Meteorological Department & http://www.tmd.go.th/ \\
\hline Trinidad and Tobago & Meteorological Service & http://www.metoffice.gov.tt/ \\
\hline Tunisia & National Institute of Meteorology & http://www.meteo.tn/ \\
\hline Turkey & Turkish State Meteorological Service & http://www.mgm.gov.tr/ \\
\hline Turkmenistan & Administration of Hydrometeorology & no website provided \\
\hline Tuvalu & Tuvalu Met Service & http://informet.net/tuvmet/ \\
\hline Uganda & Department of Meteorology & http://www.meteo-uganda.net/ \\
\hline Ukraine & Ukrainian Hydrometeorological Center & http://www.meteo.gov.ua/ \\
\hline United Arab Emirates & National Center for Meteorology and Seismology & http://www.ncms.ae/english/ \\
\hline Venezuela, Bolivarian Rep. & Instituto Nacional de Meteorología e Hidrología & http://www.inameh.gob.ve/ \\
\hline Viet Nam & Hydrometeorological Service & http://www.nchmf.gov.vn/ \\
\hline Yemen & Yemen Meteorological Service & http://www.yms.gov.ye/ \\
\hline Zambia & Zambia Meteorological Department & http://www.zmd.gov.zm/ \\
\hline Zimbabwe & Zimbabwe Meteorological Services Department & http://www.weather.co.zw/ \\
\hline
\end{tabular}

Table A2. Weather service supply channel of the private sector.

\begin{tabular}{cc}
\hline Weather Company & Website \\
\hline AccuWeather & https://www.accuweather.com/ \\
\hline 3BMeteo & http://www.3bmeteo.com \\
\hline Aerospace and Marine International (AMI) & http://www.amiwx.com/ \\
\hline Agricultural Weather Information Service (AWIS) & http://www.awis.com/ \\
\hline Air Science Consultants, Inc. & http://www.skywatchweather.com/ \\
\hline Alert Weather Services, Inc. & http://www.alertweather.com/ \\
\hline Applied Meteorological Engineering Consulting Service (AMECS) & http://www.amecs.co.jp/ \\
\hline AnythingWeather.com & http://www.anythingweather.com/ \\
\hline ATMOGRAPH ModelVis & http://www.atmograph.com/ \\
\hline AtmosForecast & http://www.atmosforecast.com/ \\
\hline Atmospheric and Environmental Research (AER) & https://www.aer.com/ \\
\hline Aura & http://www.aura.com.pl \\
\hline Automated Weather Source & https://www.earthnetworks.com/
\end{tabular}


Table A2. Cont.

\begin{tabular}{|c|c|}
\hline Weather Company & Website \\
\hline Baron Services & http://www.baronweather.com/ \\
\hline Belginur & http://www.belgingur.is \\
\hline Bioweather Service & http://www.bioweather.net/ \\
\hline Blue Sky Wetteranalysen & http://www.blueskywetter.at \\
\hline ClimaData Corp. & http://www.climadata.com/ \\
\hline Climatological Consulting Corporation & http://www.ccc-weather.com/ \\
\hline Climet Systems & http://www.climetsystems.com/ \\
\hline Commanders Weather Corporation & https://www.commandersweather.com/ \\
\hline CompuWeather, Inc. & https://www.compuweather.com/ \\
\hline Connecticut Weather Center, Inc. & http://www.ctweather.com/ \\
\hline Consultingweather.com & http://consultingweather.com/ \\
\hline Continental Weather and Earth Sciences, Inc. & http://www.continentalweather.com/ \\
\hline Cox Weather Services & http://www.coxweatherservices.com/ \\
\hline CTC(Challenging Tomorrow's Changes) & http://www.weather-eye.com/ \\
\hline CustomWeather, Inc. & http://www.customweather.com/ \\
\hline DayWeather Inc. & http://www.dayweather.com/ \\
\hline DBS Weather Impact Corp. & http://www.bridgesights.com/ \\
\hline Disaster Warning Network, Inc. & http://www.disasterwarning.com/ \\
\hline Early Alert, Inc. & http://www.earlyalert.com/ \\
\hline Earth Communication Provider & https://n-kishou.com/ \\
\hline EJS Weather & http://www.ejsweather.com/ \\
\hline Expert Weather Investigations (EWI) & http://www.expertweather.com/ \\
\hline Fair Skies Consulting & http://fairskiesconsulting.com/ \\
\hline FleetWeather, Inc. & http://www.fleetweather.com/ \\
\hline Forecasting Consultants LLC & http://www.forecastingconsultants.com/ \\
\hline ForeFlight & http://www.foreflight.com/ \\
\hline Forensic Weather Consultants & http://www.weather-consultants.com/ \\
\hline Fox Weather, LLC & http://www.foxweather.com/ \\
\hline Franklin Japan & https://www.franklinjapan.jp/ \\
\hline Freese-Notis & http://www.weather.net/ \\
\hline Golden Gate Weather Services & http://ggweather.com/ \\
\hline Great Circle & http://www.greatcircle.be \\
\hline Great Lakes Weather Service & http://www.greatlakesweatherserv.com/ \\
\hline Happy Life Expert (HALEX) & http://www.halex.co.jp/ \\
\hline Hermess & http://www.hermess.nl \\
\hline Hurricane by Kitty Code & http://kittycode.com/ \\
\hline HurricaneMapping & http://www.hurricanemapping.com/ \\
\hline Idokep & http://www.idokep.hu \\
\hline $\begin{array}{l}\text { International Meteorological and Oceanographic Consultants } \\
\text { Co. LTD (iMOC) }\end{array}$ & http://www.imocwx.com/ \\
\hline ION Weather, Inc. & http://www.ionweather.com/ \\
\hline iWeatherNet & http://www.iweathernet.com/ \\
\hline iWindsurf.com & http://www.iwindsurf.com/ \\
\hline Jenifer Clark's Gulfstream & http://www.erols.com/ \\
\hline Japan Weather Association (JWA) & https://tenki.jp/ \\
\hline Lake Street Consulting & http://www.lakestreetconsulting.co.uk \\
\hline Life Business Weather (LBW) & http://tenki.lbw.jp/ \\
\hline Marine Weather Center & http://www.mwxc.com/ \\
\hline MBC & http://www.mbc.co.jp/ \\
\hline
\end{tabular}


Table A2. Cont.

\begin{tabular}{|c|c|}
\hline Weather Company & Website \\
\hline Meteorological Engineering Center (MEC) & http://www.meci.jp/ \\
\hline Meridian Environmental Technology Inc. & http://www.meridian-enviro.com/ \\
\hline Meteo News & http://www.meteonews.ch \\
\hline Meteoblue & http://www.meteoblue.com \\
\hline MeteoGroup & http://www.meteogroup.com/ \\
\hline Meteologica & http://www.meteologica.com \\
\hline Meteomatics & http://www.meteomatics.com \\
\hline Meteopress & http://www.meteopress.cz \\
\hline Meteorological Solutions Inc. & http://www.metsolution.com/ \\
\hline MeteoServices & http://www.meteoservices.be \\
\hline MeteoStar & http://www.meteostar.com/ \\
\hline MetLoop Precision Weather Technologies & http://www.metloop.com/ \\
\hline Metro Weather, Inc. & http://www.metroweather.com/ \\
\hline Mobile Weather Team, Inc. & http://www.mobileweather.com/ \\
\hline MountainWeather & http://www.mountainweather.com/ \\
\hline New England Weather Associates & http://www.newenglandweather.com/ \\
\hline NY NJ PA Weather & http://www.nynjpaweather.com/ \\
\hline Ocean-Pro & http://www.ocean-pro.com/ \\
\hline Palm Beach Post & http://www.palmbeachpost.com/ \\
\hline Planalytics & http://www.planalytics.com/ \\
\hline Qwikcast & http://www.qwikcast.com/ \\
\hline Sailing Weather Service & http://www.sailwx.com/ \\
\hline SHIMADZU Business System (SBS) & http://tenki.shimadzu.co.jp/ \\
\hline ScoutLook Weather & http://www.scoutlookweather.com/ \\
\hline Shade Tree Meteorology LLC & http://www.shadetreemeteorology.com/ \\
\hline Skyview Weather & http://www.skyviewweather.com/ \\
\hline Sapporo Information Network (SNET) & http://www.sapporotenki.jp/ \\
\hline Speedwell & http://www.speedwellweather.com/ \\
\hline StatWeather & http://www.statweather.com/ \\
\hline Storm Shield Weather Radio App & http://www.stormshieldapp.com/ \\
\hline StormNow & http://www.stormnow.com/ \\
\hline Stormpulse & http://www.stormpulse.com/ \\
\hline StormStock & http://www.stormstock.com/ \\
\hline Sunny Spot & https://www.sunny-spot.net/ \\
\hline Surflegend & http://www.surflegend.co.jp/ \\
\hline Swift Weather & http://www.swiftwx.com/ \\
\hline Tactical Weather & http://www.tacticalweather.com/ \\
\hline TBS & http://www.tbs.co.jp/weather/ \\
\hline Tempest Tours Storm Chasing Expeditions & http://www.tempesttours.com/ \\
\hline The Weather Channel & http://www.weather.com/ \\
\hline The Weather Company & http://www.theweathercompany.com/ \\
\hline The Weather Medic & http://www.weathermedic.com/ \\
\hline The Weather Underground & http://www.wunderground.com/ \\
\hline Tornado Project & http://www.tornadoproject.com/ \\
\hline Unisys Weather & http://weather.unisys.com/ \\
\hline Weather 2000 & http://www.weather2000.com/ \\
\hline Weather 2020 & http://www.weather2020.com/ \\
\hline Weather Atlas & http://www.weather-atlas.com/ \\
\hline
\end{tabular}


Table A2. Cont.

\begin{tabular}{|c|c|}
\hline Weather Company & Website \\
\hline Weather Bank & http://www.weatherbank.com/ \\
\hline Weather Command & http://www.weathercommand.com/ \\
\hline Weather Currents & http://www.weathercurrents.com/ \\
\hline Weather Decision Technologies & http://www.wdtinc.com/ \\
\hline Weather Display & http://www.weather-display.com/ \\
\hline Weather Extreme & http://www.weatherextreme.com/ \\
\hline Weather for My Wedding & http://www.weatherformywedding.com/ \\
\hline Weather for You & http://www.weatherforyou.com/ \\
\hline Weather Guy & http://www.weatherguy.com/ \\
\hline Weather History Research & http://www.weatherclaims.com/ \\
\hline Weather Information Network & http://broadcast-weather.net/ \\
\hline Weather map & https://www.weathermap.co.jp/ \\
\hline Weather news & http://weathernews.com/ \\
\hline Weather or Not & http://www.weatherornot.com/ \\
\hline Weather Routing & http://www.wriwx.com/ \\
\hline Weather Source & https://weathersource.com/ \\
\hline Weather Sphere & http://www.weathersphere.com/ \\
\hline Weather street & http://www.weatherstreet.com/ \\
\hline weather TAP & http://www.weathertap.com/ \\
\hline Weather tech & http://www.wet.co.jp/ \\
\hline Weather things & http://www.weatherthings.com/ \\
\hline weather USA & http://www.weatherusa.net/ \\
\hline Weather Watch Service & http://www.weatherwatchservice.com/ \\
\hline Weather Works & http://www.weatherworksinc.com/ \\
\hline WeatherNet & http://www.weathernet.co.uk \\
\hline Weathernews & http://weathernews.jp/ \\
\hline West Coast Weather & http://www.westcoastweather.com/ \\
\hline Wetteronline & http://www.wetteronline.de \\
\hline Weather Information and Communications Services LTD (WICS) & https://www.wics.co.jp/ \\
\hline Wilkens Weather Technologies & http://www.wilkensweather.com/ \\
\hline WorldWinds & http://www.worldwindsinc.com/ \\
\hline Weather Service (WS) & http://www.weather-service.co.jp/ \\
\hline WxUSA & http://www.wxusa.com/ \\
\hline ZoomRadar & http://zoomradar.com/ \\
\hline otenki & http://hp.otenki.com/ \\
\hline
\end{tabular}

\section{References}

1. Daniell, J.; Wenzel, F.; McLennan, A.; Daniell, K.; Kunz-Plapp, T.; Khazai, B.; Schaefer, A.; Kunz, M.; Girard, T. The global role of natural disaster fatalities in decision-making: Statistics, trends, and analysis from 116 years of disaster data compared to fatality rates from other causes. In Proceedings of the European Geosciences Union General Assembly Conference, Vienna, Austria, 17-22 April 2016; Volume 18.

2. Daniell, J.; Wenzel, F.; Schaefer, A. The economic costs of natural disasters globally from 1900-2015: Historical and normalised floods, storms, earthquakes, volcanoes, bushfires, drought and other disasters. In Proceedings of the European Geosciences Union General Assembly Conference, Vienna, Austria, 17-22 April 2016; Volume 18.

3. World Economic Forum. Global Risks Report 2017, 12th ed.; World Economic Forum: Geneva, Switzerland. Available online: www.weforum.org/docs/GRR17_Report_web.pdf (accessed on 11 January 2017). 
4. World Economic Forum. Global Risks Report 2018, 13th ed.; World Economic Forum: Geneva, Switzerland. Available online: www.weforum.org/docs/WEF_GRR18_Report.pdf (accessed on 17 January 2018).

5. World Economic Forum. Global Risks Report 2019, 14th ed.; World Economic Forum: Geneva, Switzerland. Available online: www.weforum.org/docs/WEF_Global_Risks_Report_2019.pdf (accessed on 15 January 2019).

6. Battiston, S. A climate stress-test of the financial system. Nat. Clim. Chang. 2016, 7, 283-288. [CrossRef]

7. Carney, M. Breaking the Tragedy of the Horizon-Climate Change and FINANCIAL stability. Speech at Lloyd's of London, England. 2015. Available online: https://www.bis.org/review/r151009a.pdf (accessed on 29 September 2015).

8. Sakhel, A. Corporate climate risk management: Are European companies prepared? J. Clean. Prod. 2017, 165, 103-118. [CrossRef]

9. Armstrong, J.A. Fair Weather: Effective Partnerships in Weather and Climate Services; National Research Council, The National Academies Press: Washington, DC, USA, 2003.

10. Dutton, J.A. Opportunities and priorities in a new era for weather and climate services. Bull. Am. Meteorol. Soc. 2002, 83, 1303-1311. [CrossRef]

11. Lazo, J.K.; Lawson, M.; Larsen, P.H.; Waldman, D.M. U.S. economic sensitivity to weather variability. Bull. Am. Meteorol. Soc. 2011, 92, 1077-1098. [CrossRef]

12. Amado, J.C.; Adams, P. Value Chain Climate Resilience: A Guide to Managing Climate Impacts in Companies and Communities. 2012. Partnership for Resilience and Environmental Preparedness. Available online: http://www.oxfamamerica.org/static/oa4/valuechainclimateresilience.pdf (accessed on 27 February 2014).

13. Kunkel, K.E.; Pielke, R.A.; Changnon, S.A. Temporal fluctuations in weather and climate extremes that cause economic and human impacts: A review. Bull. Am. Meteorol. Soc. 1999, 80, 709-720. [CrossRef]

14. Vaughan, C.; Dessai, S. Climate services for society: Origins, institutional arrangements, and design elements for an evaluation framework. WIREs Clim. Chang. 2014, 5, 587-603. [CrossRef]

15. Diaz, J.; Joseph, M.B. Predicting property damage from tornadoes with zero-inflated neural networks. Weather Clim. Extrem. 2019, 25, 100216. [CrossRef]

16. Jhong, B.C.; Huang, J.; Tung, C.P. Spatial assessment of climate risk for investigating climate adaptation strategies by evaluating spatial-temporal variability of extreme precipitation. Water Resour. Manag. 2019, 33, 3377-3400. [CrossRef]

17. Newman, J.P.; Maier, H.R.; Riddell, G.A.; Zecchin, A.C.; Daniell, J.E.; Schaefer, A.M.; Delden, H.; Khazai, B.; O'Flaherty, M.J.; Newland, C.P. Review of literature on decision support systems for natural hazard risk reduction: Current status and future research directions. Environ. Model. Softw. 2017, 96, 378-409. [CrossRef]

18. Cavelier, R.; Borel, C.; Le Cozannet, G.; Ritti, D.; Morin, D.; Chaussade, M.; Charreyron, V. Climate Services for Adaptation to Climate Change; Poster; CVT National Research Alliance for Environment [AllEnvi]: Paris, France, 2016.

19. Howard, S. Analysis of Market Transactions for Climate Services. Deliverable 4.2. MARCO. Available online: http://marco-h2020.eu/wp-content/uploads/2020/01/MARCO_D4_2_Analysis_of_market_transactions_ for_climate_services.pdf (accessed on 9 January 2018).

20. Howard, S.; Sarah, H.; Simon, H. Quantitative market analysis of the European Climate Services sector-The application of the kMatrix big data market analytical tool to provide robust market intelligence. Clim. Serv. 2020, 17, 100108. [CrossRef]

21. Cortekar, J.; Themessl, M. Report on Mapping of ERA4CS Member State's National Activities for Climate Services. Available online: http://www.jpi-climate.eu/media/default.aspx/emma/org/10890172/Deliverable+ 7+2+-+Mapping+of+national+activities+PUBLIC.pdf (accessed on 7 August 2018).

22. Manez, M.; Zölch, T.; Cortekar, J. Mapping of Climate Service Providers within Europe: Theoretical Foundation and Empirical Results; JPI Climate, Working Group 2 "Research for Climate Service Development and Deployment": Hamburg, Germany, 2013.

23. Pettifer, R.E.W. The development of the commercial weather services market in Europe: 1970-2012. Meteorol. Appl. 2015, 22, 419-424. [CrossRef]

24. Freebairn, J.W.; Zillman, J.W. Economic benefits of meteorological services. Meteorol. Appl. 2002, 9, 33-44. [CrossRef]

25. Freebairn, J.W.; Zillman, J.W. Funding meteorological services. Meteorol. Appl. 2002, 9, 45-54. [CrossRef]

26. Georgeson, L.; Maslin, M.; Poessinouw, M. Global disparity in the supply of commercial weather and climate information services. Sci. Adv. 2017, 3, e1602632. [CrossRef] 
27. Troccoli, A. Achieving valuable weather and climate services. Weather Clim. Serv. Energy Ind. 2018, 13-25. [CrossRef]

28. Tart, S.; Groth, M.; Seipold, P. Market demand for climate services: An assessment of users' needs. Clim. Serv. 2019, 17, 100109. [CrossRef]

29. Brasseur, G.P.; Gallardo, L. Climate services: Lessons learned and future prospects. Earth Future 2016, 4, 79-89. [CrossRef]

30. Giannini, V.; Bellucci, A.; Torresan, S. Sharing skills and needs between providers and users of climate information to create climate services: Lessons from the Northern Adriatic case study. Earth Perspect. 2016, 3, 236240. [CrossRef]

31. Hoa, E.; Perrels, A.; Le, T.T. From generating to using climate services: How the EU-MACS and MARCO projects help to unlock the market potential. Clim. Serv. 2018, 11, 86-88.

32. Street, R.; Jacob, D.; Parry, M.; Runge, T.; Scott, J. A European Research and Innovation Roadmap for Climate Services; European Commission: Luxembourg, 2015.

33. Li, Y.; Giuliani, M.; Castelletti, A. A coupled human-natural system to assess the operational value of weather and climate services for agriculture. Hydrol. Earth Syst. Sci. 2017, 21, 4693-4709. [CrossRef]

34. Anderson, G. The Value of Climate Services Across Economic and Public Sectors: A Review of Relevant Literature. The United States Agency for International Development (USAID). Available online: https://www.climatelinks. org/sites/default/files/asset/document/CCRD-Climate-Services-Value-Report_FINAL_0.pdf (accessed on 10 December 2013).

35. Visscher, K.; Stegmaiera, P.; Damm, A.; Hamaker-Taylor, A.; Harjanne, A.; Giordano, R. Matching supply and demand: A typology of climate services. Clim. Serv. 2019, 17, 100136. [CrossRef]

36. WMO. Manual on the Global Data-processing and Forecasting System, Volume I-Global Aspects; WMO-No. 485; WMO: Geneva, Switzerland, 2010.

37. Karatzas, A.; Johnson, M.; Bastl, M. Relationship determinants of performance in service triads: A configurational approach. J. Supply Chain Manag. 2016, 52, 28-47. [CrossRef]

38. Niranjan, T.T.; Metri, B.A. Provider-vendor-end user triad: A service quality model for IS/ITES outsourcing. J. Serv. Res. 2008, 8, 123-138.

39. Sengupta, S.; Niranjan, T.T.; Krishnamoorthy, M. Trends and directions in service triads research. Int. J. Phys. Distrib. Logist. Manag. 2018, 48, 333-360. [CrossRef]

40. Wynstra, F.; Spring, M.; Schoenherr, T. Service triads: A research agenda for buyer-supplier-customer triads in business services. J. Oper. Manag. 2015, 35, 1-20. [CrossRef]

41. WMO Members. World Meteorological Organization Members. 2020. WMO-No. 1069. Available online: https://public.wmo.int/en/about-us/members (accessed on 30 October 2020).

42. WMO. Guide to the WMO Information System; WMO: Geneva, Switzerland, 2015.

43. WMO GISC. (n.d.). WMO Global Information System Centres. 2020. Available online: https://www.wmo. int/pages/prog/www/WIS/GISCs_en.html (accessed on 10 September 2020).

44. Park, N.E.; Lee, K.J. Trends and Implications of Weather Observation and Forecasting Technology. Korea Institute of Science \& Technology Evaluation and Planning. Available online: http://www.kistep.re.kr/ getFileDown.jsp?fileIdx=2657\&contentIdx=1450\&tbIdx=BRD_BOARD (accessed on 30 November 2011).

45. Park, C.S.; Kim, S.H.; Choi, L.J.; Kim, J.W. Time-Space Integrated Numerical Forecasting Technology Development Project Focused on Preliminary Preparation for Meteorological Disasters. Science \& Technology Policy Institute. Available online: https://www.kistep.re.kr/getFileDown.jsp?fileIdx=10733\&contentIdx= 13147\&tbIdx=BRD_BOARD (accessed on 30 August 2019).

46. BAI. Status of Development Project for Numerical Forecasting Model. Board of Audit and Inspection of Korea. 2020. Available online: http://www.bai.go.kr/bai/cop/bbs/detailBoardArticle.do?mdex=bai20\&bbsId= BBSMSTR_100000000009\&nttId=126146 (accessed on 30 July 2020).

47. NWS. National Weather Service: NWS Directory of Private Weather Service Providers. 2020. Available online: https://www.weather.gov/im/metdir (accessed on 10 September 2020).

48. ISIC. International Standard Industrial Classification of All Economic Activities Revision 4; Series M: Miscellaneous Statistical Papers, No. 4 Rev. 4; United Nations: New York, NY, USA, 2008.

49. WB. World Bank Country and Lending Groups: World Bank List of Economy. 2019. Available online: https: //datahelpdesk.worldbank.org/knowledgebase/articles/906519-world-bank-country-and-lending-groups (accessed on 10 September 2020). 
50. OECD. DAC List of ODA Recipients. Available online: https://www.oecd.org/dac/financing-sustainabledevelopment/development-finance-standards/daclist.htm (accessed on 11 September 2020).

51. WMO. WMO Strategic Plan (2012-2015). 2011. Available online: https://library.wmo.int/?lvl=notice display\&id=6479\#.X2SM-GgzaUk (accessed on 30 October 2020).

52. Sharma, P.; Singh, A.K.; Agrawal, B.; Sharma, A. Correlation between weather and COVID-19 pandemic in India: An empirical investigation. J. Public Aff. 2020, e2222. [CrossRef]

Publisher's Note: MDPI stays neutral with regard to jurisdictional claims in published maps and institutional affiliations.

(C) 2020 by the authors. Licensee MDPI, Basel, Switzerland. This article is an open access article distributed under the terms and conditions of the Creative Commons Attribution (CC BY) license (http://creativecommons.org/licenses/by/4.0/). 